\title{
THE SHORT-RUN RELATIONSHIP BETWEEN INEQUALITY AND GROWTH: EVIDENCE FROM OECD REGIONS DURING THE GREAT RECESSION
}

\author{
Vicente Royuela \\ Grup d'Anàlisi Quantitativa Regional (AQR-IREA), University of Barcelona. E-mail: \\ vroyuela@ub.edu
}

\section{Paolo Veneri}

Regional Development Policy Division, Public Governance and Territorial Development, OECD, 2 rue André-Pascal, 75775 Paris Cedex 16, France. E-mail: paolo.veneri@ oecd.org (corresponding author).

\section{Raul Ramos}

Grup d'Anàlisi Quantitativa Regional (AQR-IREA), University of Barcelona. E-mail: rramos@ub.edu

Keywords: Inequality, economic growth, urban size, OECD regions

JEL codes: R11, R12, O15

This work was supported by the Secretaría de Estado de Investigación, Desarrollo e Innovación [grant number ECO2016-75805-R] 


\section{Introduction}

Since the start of the economic crisis of the late 2000s, concerns have emerged in most developed countries about the distributional effect of the crisis and recovery, as in most OECD countries, the gap between rich and poor has widened. Recent evidence shows that income inequality has a negative impact on economic growth, mainly through lower levels of social mobility due to less investment in human capital. Other works distinguish between equality of opportunities and equality of outcomes as two parallel and differentiated components of inequality (World Bank, 2006), or between structural and market inequality (Easterly, 2007) having the latter an expected positive effect on economic growth.

Some of the mechanisms underlying the relationship between inequality and economic growth might be particularly relevant at the regional level, as increasing evidence shows that local conditions can affect individual opportunities. For instance, analyses for the United States show that a neighbourhood's average income has a large impact on individuals' future earnings capacity, an effect that is roughly half of that related to parental income (Rothwell and Massey, 2015). Glaeser et al. (2009) show that more unequal cities grow more slowly once controlling for the skill distribution. In the same vein, Chetty et al. (2014) find that individual opportunities differ substantially across cities in the United States and are negatively related with inequality

One issue that deserves particular consideration and that has been less analysed in the literature is the length of the time horizon. Most of the literature has focused on the long-run relationship, while much less work exists in trying to understand the short term dynamics, even though several authors recognise different channels for different time dimensions (Forbes, 2000, Perugini and Martino, 2008). The Great Recession provides an important ground for research on the role of inequality and its interaction with the regional urban structure in the last decade. Regions with different levels of inequality might respond differently to the economic cycle. At 
the same time, the effects of economic shocks can be heterogeneous by type of urban structure: in Europe highly urbanised regions were found to be particularly sensitive to the Great Recession (Dijkstra et al., 2015).

This work provides new empirical evidence on the relationship between income inequalities and economic growth between 2003 and 2013 in a large sample of regions, including 15 OECD countries. Of the few works that have tried to explain such a relationship at the regional scale, most refer to regions within a single country, especially the United States (Frank, 2009; Fallah and Partridge, 2007; Partridge, 2006, among others), although some analyses have covered European regions (Ezcurra, 2007, 2010; Perugini and Martino, 2008; Rodríguez-Pose and Tselios, 2010). To the best of our knowledge, no works focus on the short-run relationship between inequality and growth at the regional level or cover the periods before and after the Great Recession. Including this period makes it possible to consider the role of inequality for regional resilience to economic shocks.

This paper also focuses on the role of urban structure as a factor potentially affecting the inequality-economic growth relationship. Using a consistent definition of city helps identify the extent of urban concentration within regions while at the same time limiting the bias introduced by different administrative definitions across countries. The relationship between city size and economic growth has been recently analysed by Frick and Rodríguez-Pose (2016) for a wide sample of countries and Fothergill and Houston (2016) for the specific case of the United Kingdom. Their main result is that the prevailing view of a positive relationship between economic growth and city size does not hold.

We estimate panel models with country fixed effects and we consider two sets of instruments for inequality, trying to mitigate endogeneity concerns. The main findings show that inequality and economic growth are negatively associated, particularly since the start of the economic 
crisis, suggesting that more inclusive societies might foster regional resilience to economic shocks. Moreover, the link between inequality and growth is affected by urban size, with a stronger negative relationship in regions where most people live in medium to large cities.

Next, section 2 provides the rationale for analysing the relationship between inequality and growth at the sub-national level. It also reviews the mechanisms through which inequality can affect economic growth. Section 3 presents the data and the empirical model, while section 4 presents the main results. Section 5 concludes.

\section{Theoretical arguments and empirical findings: A view from the literature}

The bulk of the literature on the inequality-economic growth relationship tackles the national scale as the unit of analysis and focuses on mechanisms that play their role mostly in the long run. Ehrhart (2009) and Galor (2009) provide comprehensive overviews of theories and empirical evidence, a recent critical survey of the empirical works is provided by Neves and Silva (2014), while de Dominicis et al. (2008) and Neves et al. (2016) offer meta-analysis on the relationship between inequality and economic growth. Still, only a few studies have tried to explain the inequality-growth nexus at the sub-national level, although it is relevant for several reasons.

First, smaller spatial entities better reflect the actual conditions experienced by people where they live, and this might reduce a potential omitted variable bias generated by national averages and incomparability across countries. Second, the use of regional data also helps to magnify how small disparities in initial conditions affect economic growth (Partridge, 2005), and it allows researchers to better account for patterns of urban agglomeration. Such patterns are certainly linked to inequalities through mechanisms of sorting the most talented individuals, selecting the most productive firms, and agglomerating the advantages of cities. 
Third, many factors affecting people's well-being and the business environment (e.g., crime, access to services, etc.) are also likely to be important at the local level. In particular, the socioeconomic characteristics of the communities where people actually live can affect individual opportunities (and choices), yielding different economic outcomes. Investment in human capital can be shaped by local conditions, including life expectancy (Rodríguez-Pose and Tselios, 2010), which can largely differ across regions: the difference between the best and the worst performing OECD region in terms of life expectancy is 15 years, more than double than among countries (OECD, 2014).

Finally, compared with countries, regions are also much more open economies. Capital and labour - particularly a highly educated workforce - can move across regions at a lower cost and tend to move to places where they can enjoy higher returns. Cities certainly have an advantage in attracting capital and labour, thanks to more efficient provision of public services (due to economies of scale) and agglomeration economies. In principle, perfectly mobile production factors should yield, in equilibrium, an optimal allocation of resources with no spatial inequalities. However, even in the presence of perfect factor mobility, differences in initial factor endowments, sectoral specialisation, and agglomeration externalities can widen interregional disparities (Rice and Venables, 2003). An initial higher level of specialisation in sectors requiring more highly skilled workers can attract further highly skilled labour and increase the gap in earnings. A possible consequence is that factor mobility increases income inequalities in relatively rich regions while reducing those in worse-off regions (Perugini and Martino, 2008). This might determine the co-existence of a positive relationship between inequality and growth at the regional level, with a negative relationship at the country level (Fallah and Partridge, 2007). Glaeser et al. (2009) report a positive association at the city level in the U.S. which becomes negative once skills distribution are controlled for. 
Regarding the mechanisms underlying inequality-growth relationships, recent evidence at the national level shows that while in the short run a positive relationship predominates, in the long run the reverse is observed (Halter et al., 2014). ${ }^{1}$

\section{Long-run factors:}

The classical approach to the role of physical and human capital accumulation suggests that savings rates increase with wealth and that wealthier people have a higher marginal propensity to save, and as a result, in more unequal societies, aggregate investment in physical capital will be relatively higher, fostering economic growth (Barro, 2000).

The modern paradigm focuses on the role of human capital accumulation rather than on investment in physical capital, the former being the major driver of growth in developed economies (Galor and Moav, 2004). According to Tselios (2008), the optimal level of schooling depends on the distribution of income, as the supply and demand curves have a different shape for different income groups. Another argument is that more equal societies give people greater opportunities to invest in human capital because of imperfections in the financial and credit markets that prevent worse-off individuals from carrying out such costly investments. In this view, more equal societies can be seen as opportunity enhancing, given the decreasing returns on investment in education at the individual level and the fact that households' wealth is a major determinant of such investments. Recent empirical analyses further support the idea that obstacles to human capital accumulation drive the negative relationship between inequality and growth (Cingano, 2014).

Economic incentives also play an important role in the long run. Societies in which ability is rewarded stimulate individual effort, productivity, and risk taking (Voitchovsky, 2005). These

\footnotetext{
${ }^{1}$ Table A1.1 in Appendix 1 summarises the main theoretical arguments that have been put forward to uncover such a complex relationship and distinguishes mechanisms operating in the long-run from those having a role in a short-time horizon as well as growth-enhancing factors from growth-hindering factors.
} 
economic incentives also affect the accumulation of human capital and the effort to seize the returns of skills, although in the low part of the wage distribution, they can be counterbalanced by feelings of unfairness (Akerlof and Yellen, 1990).

Political economy factors also matter. Persson and Tabellini (1994) and Alesina and Rodrik (1994) argue that in relatively more unequal societies, people vote for higher taxation and redistribution. Higher taxation has a negative effect on incentives to invest, which, in turn, negatively affects economic growth.

\section{Short-run factors:}

One channel through which inequalities can affect economic growth in the short-run is political instability. Alesina and Perotti (1996) provide cross-country evidence that inequalities generate higher levels social discontent and political instability, which in turn yields lower levels of investment and economic growth At the regional level, this channel would play a role through higher levels of urban segregation or crime rates rather than institutional instability. In research on US metropolitan areas, $\mathrm{Li}$ et al. (2013) find that residential segregation by skills and race which is likely to be reflected also in income levels - is negatively correlated with economic growth.

A strand of literature argues that increasing inequality can affect both demand for and supply of credit (Morelli and Atkinson, 2015). Low-income households tend to increase their levels of indebtedness in order to maintain the stability of their consumption patterns. From a supply side, increasing loans to more risky individuals due to financial liberalization are likely to generate further instability in the financial system (Rajan, 2010; Bazilliers and Hericourt, 2012). Thus, inequality is likely to cause unhealthy credit booms, which can suddenly degenerate into financial instability (Perugini et al., 2016). 
Short-term effects of inequality on economic growth can be determined by the existence of convex saving functions and high-risk propensity of wealthier individuals (Kuznets, 1955; Kaldor, 1955). A higher concentration of resources ensures that there will be at least a limited number of sufficiently rich investors to take on risky but high-return investment projects, which can in turn ensure higher growth rates. As these mechanisms are of a purely economic nature, they are likely to materialise relatively quickly (Halter et al., 2014).

Last, on the demand side, the link between inequalities and growth depends on the balance between two different effects: market size and the dynamic price effect: in a short time horizon, innovation is affected by the demand for new products. The latter requires innovation, which in turn drives economic growth. In a more equal society, more individuals will be able to buy a new product, stimulating innovation by firms. However, the richest individuals have a greater willingness to pay for new goods and higher prices can be applied by monopolistic producers, stimulating further innovation (Bertola et al., 2006; Foellmi and Zwerimuller, 2006).

Summarising, the existing empirical evidence on the inequality-growth nexus over the shortrun tends to confirm a positive association driven by different factors, as found for European regions in Perugini and Martino (2008) and Rodríquez-Pose and Tselios (2010). Grijalva (2012) found an inverse U-shaped relationship over both 5-year and 10-year periods using a large panel of countries. Going from the short to the medium-run time horizon, the relationship shifts downwards, meaning that the relationship turns negative at a lower level of inequality: Ezcurra (2007) finds a negative association for a sample of European regions over a ten years period. In the long-run (20-year time span) the relationship becomes linear and negative. Li and Zou (1998) and Forbes (2000) find a positive relationship over 5-year periods, while Barro (2000) finds that the relationship between inequality and growth over 10-year periods is negative for poor countries and positive for rich countries. 


\section{Data and facts}

\section{Income inequality within regions}

The data set includes 209 TL2 regions ${ }^{2}$ from 15 OECD countries, of which 10 are European (Belgium, Czech Republic, Estonia, Finland, France, Greece, Italy, Luxemburg, Spain, and the United Kingdom, accounting for $45 \%$ of all regions in the sample), four American (Canada, Chile, Mexico, and the United States, accounting for 52\% of all regions) and one Asian (South Korea, $3 \%$ of all regions). Indicators of inequality at the regional level are computed using micro-data from household income surveys publicly available or made available through the OECD Income Distribution Database, following the method applied by Piacentini (2014). Table A1.2 in Appendix 1 provides details on the data sources. For reasons of robustness, inequalities within regions are computed using several indicators related to equivalized household annual disposable income: the Gini Index, the top-bottom quintile ratio (p80-20), the top-bottom decile ratio (p90-10), the bottom decile ratio (p50-10), the top decile ratio (p90-50), and the relative poverty rate using two alternative national poverty lines, at $40 \%$ and at $60 \%$ of the median income. The analysis uses the 2003-2013 income reference period. As this is a yearly panel, interpolated inequality statistics were used, usually for one year, when data on inequality is not available on a yearly basis (i.e., Chile, Korea, and Mexico). We work with an unbalanced panel with some attrition. For 2003 the data has 10 countries; 2010 is the only year with data for all 15 countries; 13 countries for 2012 ; and 4 countries for 2013 . The only country with information for the full period is the US, while for the United Kingdom data is available only from 2010 onwards.

\footnotetext{
${ }^{2}$ TL2 regions are the higher level of OECD regions, which correspond in most cases to the principal sub-national unit of government (states or provinces). There are 214 regions in the selected countries. Due to a lack of data on individual income, inequality statistics of five of these regions are not considered: three for Canada (Yukon, Northwest Territories, and Nunavut), one for Finland (Åland), and one for Korea (Jeju).
} 
The dependent variable is the annual growth rate of per capita GDP in PPP-adjusted US dollars. A set of control variables was included to account for socio-economic and institutional factors that can have a role in regional economic growth. The basic statistics of the income distribution indicators are summarised in table A1.4 in Appendix 1, where one can see that given the short period under consideration, most of the variation in inequality is due to cross-sectional differences, as the variation in time is much smaller.

\section{Inequality, economic growth and urban concentration}

The strong decline in economic growth rates subsequent to the Great recession has been heterogeneous across regions and countries (OECD, 2013). A positive association is observed across OECD regions between GDP growth and several measures of income inequality (Table 1). However, the sign of the correlations becomes negative when controlling for regions and time-fixed effects.

\section{[TABLE 1]}

It is documented that income inequality and urban size are positively associated (Baum-Snow and Pavan, 2013). Urbanisation and income inequality can be interpreted as the spatial concentration of human and physical capital in the process of development (Castells-Quintana and Royuela, 2014). By determining the allocation of resources across space and individuals, the interaction between urbanisation and inequality is therefore expected to have implications in terms of economic growth (Kim and Kim, 2003). The first step to exploring this issue is to assess the levels of inequality in regions by distinguishing the type and size of urban settlements. Urban population is identified using the functional urban areas (FUAs) defined by OECD (2012). The use of FUAs is a relevant contribution of this study, as it helps assess the extent of urban concentration within a region without relying on countries' existing administrative definitions of cities, which can introduce biases in the analysis. 
Regions were classified in three groups according to their urban structure: 99 regions that are either rural (11 regions) or where the largest urbanisation share is observed in smaller cities (88 regions with cities with less than 500,000 inhabitants), 63 in medium-sized cities (between 500,000 and 1.5 million inhabitants) and 52 in large cities (more than 1.5 million inhabitants). Most (56\%) European regions have small cities, 3 out of 7 Korean regions (43\%) have large cities, while the American regions of the sample are distributed among the three categories (38\% small, $32 \%$ median, and $30 \%$ large cities). ${ }^{3}$

In the sample of regions, inequalities are smaller the smaller the size of cities, though with considerable heterogeneity (Figure 1). This general evidence is robust to the use of several indicators of inequality, and differences are particularly strong for poverty rates and for the bottom decile ratio (Table 2). Several interpretations arise: more talented individuals tend to congregate in large cities where the returns to talent are higher and where there are more productive firms paying higher wages (Behrens et al., 2014); agglomeration economies can be a source of additional wage premium, increasing the level of inequalities; and, as in the Harris and Todaro (1970) model, the expected income of a potential immigrant depends on the probability of finding a job, which is more likely to happen in expanding cities. As the 'Todaro Paradox' explains, it can be the case that the inflow of workers to the urban sector exceeds urban labour demand, and it can result in increasing unemployment, which in turn increases inequality. This result can also arise in situations where international migrants are directed to gateway cities, which are usually the largest cities (Royuela, 2015).

\section{[FIGURE 1]}

[TABLE 2]

\footnotetext{
${ }^{3}$ Figure A1.1. in Appendix 1 displays the relative distribution of urban population by country.
} 


\section{Empirical analysis}

\section{Model specification}

The standard procedure for estimating the impact of inequality on growth is to assume a simple linear relationship where the growth rate of GDP per capita is regressed on a number of explanatory variables potentially explaining differences in growth rates, including a measure of income inequality. Specifically,

$$
\ln y_{i t}-\ln y_{i t-\tau}=\alpha+\beta \ln y_{i t-\tau}+\gamma x_{i t-\tau}+\theta Z_{i t-\tau}+\varepsilon_{i t}
$$

where $\ln y_{i t}$ is the logarithm of GDP per capita in region $i$ at time $t ; x_{i t-\tau}$ represents an income inequality measure (e.g., the Gini Index), $Z_{i t-\tau}$ is a set of control variables that account for factors underlying economic growth, and $\varepsilon_{i t}$ a random error term that varies across regions and periods. In particular, $Z_{i t-\tau}$ includes the degree and type of urban concentration, measured through the share of regional population living in cities, accounting for the size of the latter. More specifically, three classes of urban size were considered: less than 500,000 inhabitants, between 0.5 and 1.5 million inhabitants, and beyond 1.5 million. Control variables also include demographics (e.g., age structure), the sectoral shares of the economy (agriculture, industry, and construction), education levels, the labour market participation rate, and one variable related to religion at the country level based on a Herfindahl Index of diversity in religion (as in Rodríguez-Pose and Tselios, 2010). Definitions and sources for all variables can be found in table A1.3 in Appendix 1.

The estimation of the empirical model requires to tackle a list of econometric problems such as reverse causality and unobserved time-invariant region-specific characteristics and spatial dependence. As former aspects, factors such as technology, climate, institutions, and any other country-specific variable may be important determinants of growth rates and may be correlated 
with the explanatory variables considered in the model. Many factors other than our controls are typically unobservable. By assuming those factors are constant over time and using longitudinal data, the suggested specification results in a modified panel data version of the previous equation, where one can control for unobservable factors. One of the possibilities is the use of regional fixed effects (FE). This procedure is supposed to account for most omitted variable bias. Nevertheless, it reduces the degrees of freedom and the measurement-error bias is aggravated, as the signal-to-noise ratio is further reduced by only using variation within regions (Neves et al., 2016). The estimated coefficients would then only reflect the effect of time variation within regions, and when the phenomenon under analysis mostly varies crosssectionally, the method may produce inaccurate results (Partridge, 2005). In our sample, the overall standard deviation of the Gini Index is 0.075 , the between standard deviation being 0.072 and the within standard deviation being 0.021. Consequently, the FE models would account for only a small fraction of the variation of inequality, and "the long-run cross-sectional effects would be subsumed into the fixed effects" (Fallah and Partridge, 2007: 381), in turn producing potentially misleading results (Barro, 2000). In addition, the short time intervals considered in this work and in other similar analyses (Rodríguez-Pose and Tselios, 2010) further question the use of FE to account for the omitted variable bias. Forbes (2000) also recalls that in panels with a limited time series length the estimation by fixed effects is not consistent, i.e., the size of the bias is much more important for the endogenous variable than for other righthand side. Finally, we also take into account the possibility of spatial dependence, as reported in Ezcurra (2007) and Perugini and Martino (2008). Ezcurra estimates a spatial error model considering inverse a spatial matrix based on the distance between the centroids, while Perugini and Martino (2008) apply both a spatial lag model and a spatial error model using a binary firstorder contiguity matrix. 
Taking into account the previous exposition, our strategy to account for the omitted variable bias and for a large source of spatial heterogeneity is to include country dummies, and a set of controls. More specifically, the model in equation [1] is modified as follows:

$$
\ln y_{i t}-\ln y_{i t-\tau}=\alpha+\beta \ln y_{i t-\tau}+\gamma x_{i t-\tau}+\theta Z_{i t-\tau}+\Xi_{c}+\eta_{t}+\varepsilon_{i t}
$$

where $\Xi_{c}$ is a vector of country effects and $\eta_{t}$ represents a vector of time-specific effects.

The option of estimating a dynamic panel model using the System GMM estimator was discarded for two reasons. First, the time dimension is too short for some countries, such as the United Kingdom. Second, System GMM is designed with the assumption that the only available instruments are 'internal' - based on lags of the instrumented variables (Roodman, 2009), and in our case these are correlated with the error term. ${ }^{4}$

Reverse causality is treated by means of an instrumental variable approach, as it addresses the potential endogeneity of the lagged value of GDP per capita and inequality. One of the main strengths of our work is the amplitude of the regional coverage: more than 200 regions in 15 different countries. Nevertheless, identifying valid instruments in such a sample is not straightforward. Taking this into account, we have followed a double strategy.

In the first stage we have collected the following set of instruments: the murder rate, the elderly rate, and the share of registered voters who voted during general elections. These variables are used as instruments capable of capturing mainly the channels associated with political economy and political instability.

Atems (2013) explores the way the political affiliation of US counties affects the inequalitygrowth relationship and finds a strong heterogeneity. By considering the share of voters and the

\footnotetext{
${ }^{4}$ The Hansen test with a reasonable number of instruments was robustly rejected for different geographical areas due to lags of the internal instruments, methods differences (between GMM and orthogonal System GMM), endogenous/predetermined consideration of the other control variables, and inclusion of external instruments.
} 
elderly rate, one can capture part of the political economy channel and part of the demand dynamics. In the very short term the demographic structure of the regions is assumed as exogenous. Similarly, the functioning of democracies is a variable that, despite affecting the way inequality is associated with economic growth, has been found to have an ambiguous relationship with the latter (Doucouliagos and Ulubaşoğlu, 2008). The murder rate can be used as an indicator of political instability. As Powell et al. (2010, p. 349) conclude, there is 'little evidence of the impact of crime on economic growth in cross-country Studies.': while some studies report that crime has a significant negative influence on economic growth (Cárdenas, 2007; Peri, 2004; Gaibulloev \& Sandler, 2008), others infer that the impact is unclear (Goulas \& Zervoyianni, 2012; Burnham et al., 2004) or even non-existing (Mauro \& Carmeci, 2007; Chatterjee and Ray, 2014). We also considered the vegetation coverage of every region in order to consider permanent differences between regions (this is the only time-invariant instrument considered in our analysis). Instruments are considered both in levels and first differences. We admit that any reader can have serious concerns on this set of instruments by arguing that they hardly meet the exclusion restrictions, by having an effect on economic growth beyond the indirect effect via inequality. Consequently we are to be, first, particularly careful with the under and over identification tests, and second, with the interpretation of the results: any significant effect arising from the use of these instruments might be the result of a direct effect of these political economy related instruments.

These caveats calls for a parallel strategy focused on exploiting an alternative channel through with inequality may affect economic growth. For that purpose we build a new instrument, using a two-step procedure following Brückner (2012, 2013) and Castells-Quintana (2016). We define an instrument based on Bartik's (1991) industry mix for economic growth and we use it to build a valid instrument for inequality in the growth equation. We follow a new version of this instrument developed in Détang-Dessendre et al. (2016). First, we regress inequality as 
dependent variable on economic growth using an IV approach. By construction, the residual of this equation captures any variation in the inequality measure that is not due to economic growth.

As shown in more detail in Appendix 2, economic growth drives subsequent increases in overall and top income inequality and decreases in bottom income inequality. The derived instruments are free of these market-driven inequality changes. Despite our efforts to demonstrate that our generated instruments are valid, we again assume that they are based on the assumption that the sectoral share of every economy is not affecting subsequent inequality evolution. Again, we are particularly careful with the under and over identification tests and we assume that our approach may lower endogeneity concerns but is hardly likely to remove it completely.

\section{$\underline{\text { Econometric results }}$}

Table 3 shows the estimates of the pooled OLS panel estimates with country fixed effects for different inequality measures. Our results report non-significant parameters for global measures of inequality (the Gini index and the 80-20 and 90-10 ratios). These measures hide a conflicting relationship with top-income inequality, which is marginally positive (10\% of confidence), and bottom-income inequality and poverty indicators, which are significant and negative. Such results call for a specific focus on the different types of inequality and accommodate both to positive results (Perugini and Martino, 2008; Rodríguez-Pose and Tselios, 2010) and negative ones (Ezcurra, 2007). Regarding the coefficients of the other control variables, displayed in table A1.5 in Appendix 1, those related to GDP per capita and urban concentration are never significantly different from zero. On the other hand, the coefficients related to educational attainment and labour participation are positive and negative in sign, respectively, and statistically significant. The sectoral composition shows significant parameters, which are 
significantly positive for regions with high shares in Agriculture and Industry. Finally, the coefficient related to religious diversity was always positive and significant.

Table 4 shows results obtained with the random effects specification, including those with instrumental variable regressions considering standard instruments (IV1) and regressions considering industry mix derived instruments (IV2). As reported above, there may be some concerns on the suitability of our procedures for treating endogeneity. Consequently, from now on, we will interpret our results in terms of association rather than being strict in terms of causality interpretation. The estimates are performed for a global inequality statistic (the Gini index) and for the 90-50 and 50-10 ratios in order to capture any complex relationship between inequality resulting from different parts of the income distribution. ${ }^{5}$

The random effects estimates of the Gini index replicate the results obtained in Table 3 for the pooled OLS regressions. Our heterogeneous results are in line with the meta-analysis of Neves et al. (2016) at the country level, who highlight that "although the average impact of inequality is not significant, there is a high degree of heterogeneity in the reported effect sizes" (Neves et al., 2016, p 397). In the previous section we find a heterogeneous association between economic growth and inequality by city size. Columns 2, 4 and 6 of table 4 show incremental parameters of income inequality as the shares of population in medium and large cities increase. Column 2 shows the random effects results and displays significant and negative parameters for inequality measures in larger cities. This result is also obtained for top and bottom income inequality, although again a positive and significant parameter is found for top income inequality. At this stage we take into account the possibility of spatial effects, which are well documented in regional growth regressions in EU regions (Ezcurra, 2007; and Perugini and Martino, 2008). We have performed a list of panel regressions considering spatial error models, assuming both

\footnotetext{
${ }^{5}$ Results are robust to the use of other indicators of income inequality and can be made available by the authors upon request.
} 
contiguity and inverse distance matrices. We have performed these regressions considering a balanced panel of regions, as required by these procedures. Table A1.6 in the Appendix 1 displays the main results, including the Pesaran (2004) cross-sectional dependence test for spatial models. The results show that in fact there is spatial dependence in the residuals. Nevertheless, and consistently with what found by Ezcurra, (2007) and Perugini and Martino (2008), the main results hold after addressing residual's spatial dependence: a positive impact of top income inequality on economic growth, plus significant and negative parameters for inequality larger cities. Even though we assume the potential consequences of not considering spatial dependence and as far as the main results of our analysis are robust to its consideration, as in Perugini and Martino (2008) next we provide separate regressions for accounting for endogeneity.

Thus, when we instrument inequality with so-called political instability channels (IV1), inequality turns statistically significant, though this does not occur for the market-free instruments (IV2). ${ }^{6}$ The coefficient related to top income inequality is negative and statistically significant under IV1 and but not significant under IV2, while the coefficient related to bottom income inequality is always negative and statistically significant.

IV regressions display significant and negative parameters for the Gini index in larger cities. This result is also obtained for top and bottom income inequality, although it is not robust for IV2 sets of instruments.

As a robustness, separate regressions for groups of regions according to their city size were performed (Table A1.7 in Appendix 1). ${ }^{7} \mathrm{We}$ find again the significant and negative association

\footnotetext{
${ }^{6}$ As the instruments used in the growth equation are generated regressors, standard errors on the slope coefficients are usually incorrect for hypothesis testing. However, as noted by Brückner (2013), in the special case of testing that slope coefficients are equal to zero these standard errors are correct.

${ }^{7} \mathrm{We}$ also considered additional regressions by splitting the subsample of regions with smaller cities below and above 200,000 inhabitants. The obtained results remained unchanged, but we agree with one of the referees, that it is an interesting aspect to be considered as further research.
} 
between inequality on economic growth in regions with medium and large cities, particularly when using the bottom income ratio. Overall, inequality is higher in regions with larger cities, but further increases of inequality in these regions are associated with lower economic growth rates.

\section{[TABLE 3]}

\section{[TABLE 4]}

Credit market imperfections and market size effects are potential mechanisms underlying the negative effects of inequality on economic growth. Possible explanations include stronger social ties in small cities and rural areas, which could limit the consequences of the imperfections in the credit markets. As for the market size effect, this might be linked to the high costs of living in cities (Combes et al., 2012), which are likely to depress particularly fixed salaries as well as government transfers and social benefits, usually established nationally rather than adjusted to local prices.

The impact of the business cycle: Inequality and growth before and after the Great Recession

Empirical findings on the inequality-growth relationship can be importantly affected by the time span considered. ${ }^{8}$ Results obtained in the short time-horizon considered here are hardly comparable with works such as Partridge (2005), which covers a period of 40 years for US states and finds a positive link between inequality and long-run economic growth, while FE results were much more ambiguous. Rodríguez-Pose and Tselios (2010) over the 1994-2001 period and Perugini and Martino (2008) over two samples (1995-2004 and 2000-2004) also find a positive link in OLS estimates and non-significant results for the FE results, in line with our results, while Ezcurra (2007) over the 1993-2002 period reports a negative estimate. Our

\footnotetext{
${ }^{8}$ In fact, it is also reasonable to argue that the results might be affected by alternative definitions of the dependent variable. We also developed our estimates considering two-year growth rates and exponentially smoothed data for both one year and two years growth rates. The main conclusions of our work hold. The results can be obtained from the authors upon request.
} 
analysis includes the years before and after the economic crisis began in 2008. This makes it possible to verify whether the role of inequality on economic growth changed in a period of economic shocks. The hypothesis is that less unequal regions might show higher resilience to economic shocks, especially among regions in which inequality is relatively high, such as those with large metropolitan areas.

Table 5 presents the results of a model that considers separate estimates for two sub-periods. The first model reports estimates of inequality on economic growth until 2006 (including the growth rate for 2006-07). The next sub-period already takes into account the downturn, as it considers inequality in 2007 and economic growth from 2007-08 onwards. ${ }^{9}$ Our results, which are robust to the type of inequality indicator, point to a clear effect of the Great Recession in turning the parameter negative and significant.

\section{[TABLE 5]}

These results confirm the idea that lower levels of inequality might have been relevant as an element of regional resilience against the shock of the crisis. Regions with smaller cities were less harmed by inequality during the Great Recession than regions with large cities. Even though the difficulty in reporting causality in this relationship, we believe that there is a significant association even after several aspects are considered. A possible interpretation is that places with lower levels of inequality - such as regions with relatively small cities - might have more room for increasing inequality by increasing the spatial concentration of economic activity. The benefits of agglomeration might, in fact, overcome the costs of higher levels of inequality.

\footnotetext{
${ }^{9}$ We also tried with subsamples to divide the period with observations until 2007 and 2008 . The results are robust for such alternative specifications.
} 


\section{Concluding remarks}

This paper analyses the association between income inequality and economic growth. The patterns of association between income inequality, urban size, and economic growth were investigated using a panel of regions from 15 OECD countries covering three continents over the period between 2003 and 2013. The obtained results provide support for a negative association between inequality and economic growth, especially when the former is measured focusing on the lower part of the income distribution. Such relationships are stronger in large cities, while in regions characterised by rural areas and small cities the relationship is nonsignificant. These findings are stronger from the start of the economic crisis.

Credit market imperfections and market size effects are potential mechanisms underlying the obtained results. If imperfections in the credit market are lower in less populated areas due to less asymmetric information flows, and closer contacts, this could lead to lower levels of inequality and to better incentives for wealth accumulation and higher economic growth. The market size channel could operate in the opposite direction: the higher costs of living in an urban area are not equally shared by its inhabitants, thus increasing within-region inequalities and depressing economic growth as fewer consumers can afford to buy goods.

Future research could advance in three different, although related, directions: first, exploring the reasons for the increasing importance of inequality within cities and metropolitan areas and between regions is a relevant and scarcely analysed topic, second, testing alternative theories on the mechanisms through which urban size can alter the relationship between inequality and economic growth, especially in the short-run, and third working with city observations, what would improve the definition of the units of analysis. 


\section{References}

Akerlof, G.A., and Yellen, J.L. (1990) The Fair Wage-effort Hypothesis and Unemployment. The Quarterly Journal of Economics 105(2): 255-283

Alesina, A. and Perotti, R. (1996) Income Distribution, Political Instability, and Investment. European Economic Review 40: 1203-1228

Alesina, A. and Rodrik, D. (1994) Distributive Politics and Economic Growth. The Quarterly Journal of Economics 109: 465-490

Atems, B. (2013) A note on the differencial regional effects of income inequality: empirical evidence using U.S. county-level data. Journal of Regional Science 53(4): 565-671

Barro, R.J. (2000) Inequality and Growth in a Panel of Countries. Journal of Economic Growth 5: $5-32$

Bartik, T.J. (1991) Who Benefits from State and Local Economic Development Policies? W. E. Upjohn Institute for Employment Research, Kalamazoo, Mich

Baum-Snow, N. and Pavan, R. (2013) Inequality and City Size. The Review of Economics and Statistics 95(5): 1535-1548

Bazilliers, R. and Hericourt, J. (2012) The Circular Relationship between Inequality, Leverage, and Financial Crises CEPII Working Paper http://www.cepii.fr/PDF_PUB/wp/2014/wp2014-22.pdf

Bertola, G., Foellmi, R., and Zweimüller, J. (2006) Income Distribution in Macroeconomic Models. Princeton: Princeton University Press

Brückner, M. (2012) Economic growth, size of the agricultural sector, and urbanization in Africa. Journal of Urban Economics 71: 26-36

Brückner, M. (2013) On the simultaneity problem in the aid and growth debate. Journal of Applied Econometrics 28: 126-150

Burnham, R., Feinberg, R.M., and Husted T.A. (2004) Central city crime and suburban economic growth. Applied Economics 36-9: 917-922

Cárdenas, M. (2007) Economic Growth in Colombia: A Reversal of 'fortune'?. Ensayos sobre Política Económica 25- 53: 220-259

Castells-Quintana, D. (2016) Malthus living in a slum: Urban concentration, infrastructure and economic growth. Journal of Urban Economics 92: 31-47

Castells-Quintana, D. and Royuela, V. (2014) Agglomeration, Inequality and Economic Growth. Annals of Regional Science 52: 343-366

Chatterjee, I. and Ray, R. (2014) Crime, corruption and the role of institutions. Indian Growth and Development Review 7(1): 73-95

Chetty, R., Hendren, N., Kline, P., and Saez, E. (2014) Where is the land of opportunity? The geography of intergenerational mobility in the United States. The Quarterly Journal of Economics 129(4): 1553-1623

Cingano, F. (2014) Trends in Income Inequality and its Impact on Economic Growth. OECD Social, Employment and Migration Working Papers, 163. Paris: OECD Publishing 
Combes, P.P., Duranton, G., and Gobillon, L. (2012) The Cost of Agglomeration: Land Prices in French Cities CEPR Working Papers, 9240

de Dominicis, L., Florax, R.J.G.M. and de Groot, H.L.F. (2008) A Meta-Analysis on the Relationship between Income Inequality and Economic Growth. Scottish Journal of Political Economy, 55-5: 654-682.

Détang-Dessendre, C., Partridge, M.D., and Piguet, V. (2016) Local labor market flexibility in a perceived low migration country: The case of French labor markets. Regional Science and urban Economics 58: 89-103

Dijkstra, L., Garcilazo, E., and McCann, P. (2015) The effects of the global financial crisis on European regions and cities. Journal of Economic Geography 15: 935-949

Doucouliagos, H., and Ulubaşoğlu, M.A. (2008) Democracy and economic growth: a metaanalysis. American Journal of Political Science 52(1): 61-83

Easterly, W. (2007) Inequality Does Cause Underdevelopment: Insights from a New Instrument. Journal of Development Economics 84: 755-776

Ehrhart, C. (2009) The Effects of Inequality on Growth: A Survey of the Theoretical and Empirical Literature ECINEQ Working Paper Series, 2009-107

Ezcurra, R. (2007): Is income inequality harmful for regional growth? Evidence from the European Union. Urban Studies 44: 1953-1971.

Ezcurra, R. (2010) Does Income Polarization Affect Economic Growth? The Case of the European Regions. Regional Studies 43(2): 267-285

Fallah, B.N. and Partridge M.D. (2007) The Elusive Inequality-Economic Growth Relationship: Are There Differences Between Cities and Countries. The Annals of Regional Science 41(2): 375-400

Foellmi, R. and Zweimuller, J. (2006) Income Distribution and Demand-Induced Innovations Review of Economic Studies 73(4): 941-960

Forbes, K.J. (2000) A Reassessement of the Relationship Between Inequality and Growth American Economic Review 90(4): 869-887

Fothergill, S. and Houston, D. (2016) Are big cities really the motor of UK regional economic growth? Cambridge Journal of Regions, Economy and Society, 9-2: 319-334.

Frank, M.W. (2009) Inequality and Growth in the United States: Evidence From a New Statelevel Panel of Income Inequality Measures. Economic Inquiry 47(1): 55-68

Frick, S.A. and Rodríguez-Pose, A. (2016) Average city size and economic growth. Cambridge Journal of Regions, Economy and Society 9-2: 301-318.

Gaibulloev, K. and Sandler, T.M. (2008) Growth Consequences of Terrorism in Western Europe. KYKLOS 61-3: 411-424

Galor, O. (2009) Inequality and Economic Development: The Modern Perspective. Edward Elgar Pub. Ltd

Galor, O. and Moav, O. (2004) From Physical to Human Capital Accumulation: Inequality and the Process of Development. Review of Economic Studies 71(4): 1001-1026

Glaeser, E.L., Resseger M.G., and Tobio, K. (2009), Inequality in Cities, Journal of Regional Science, 49-4: 617-646. 
Goulas, E. and Zervoyianni, A. (2012) Economic growth and crime: does uncertainty matter? Applied Economics Letters 20-5: 420-427

Grijalva, D.F. (2012) Inequality and Economic Growth: Bridging the Short-run and the Longrun. University of California, Irvine

Halter, D., Oechslin, and M., Zweimüller, J. (2014) Inequality and Growth: The Neglected Time Dimension. Journal of Economic Growth 19: 81-104

Harris, J.R. and Todaro, M.P. (1970) Migration, Unemployment and Development: A Twosector Analysis. American Economic Review 60: 126-142

Kaldor, N. (1955) Alternative theories of distribution. Review of Economic Studies 23(2): 83100

Kaldor, N. (1957) A Model of Economic Growth. Economic Journal 67: 591-624

Kim, E. and Kim K. (2003) Impacts of the development of large cities on economic growth and income distribution in Korea: A multiregional CGE model. Papers in Regional Science 82: $101-122$

Kuznets, S. (1955) Economic growth and income inequality. American Economic Review 45(1): $1-28$

Li, H. and Zou, H. (1998) Income Inequality is not Harmful for Growth: Theory and Evidence Review of Development Economics 2(3): 318-334

Li, H., Campbell H., and Fernandez S. (2013) Residential Segregation, Spatial Mismatch and Economic Growth across US Metropolitan Areas. Urban Studies 50(13): 2642-2660

Morelli, S. and Atkinson, A.B. (2015) Inequality and Crises Revisited. Economia Politica 32(1): $31-51$

Mauro, L. and Carmeci, G. (2007) A Poverty Trap of Crime and Unemployment. Review of Development Economics 11(3): 450-462

Neves, P.C., Afonso, O., and Tavares Silva, S. (2016), A Meta-Analytic Reassessment of the Effects of Inequality on Growth, World Development, 78: 386-400.

Neves, P.C. and Tavares Silva, S. (2014) Inequality and Growth: Uncovering the Main Conclusions from the Empirics. Journal of Development Studies 50(1): 1-21

OECD (2012) Redefining 'Urban': A New Way to Measure Metropolitan Areas. Paris: OECD Publishing

OECD (2013) OECD Regions at a Glance 2013. Paris: OECD Publishing

OECD (2014) How's Life in Your Region? Measuring Regional and Local Well-being for Policy Making. Paris: OECD Publishing

Partridge, M.D. (2005) Does Income Distribution Affect US State Economic Growth?. Journal of Regional Science 45: 363-394

Peri, G. (2004) Socio-Cultural Variables and Economic Success: Evidence from Italian Provinces 1951-1991. Topics in Macroeconomics 4-1: 1- 34

Persson, T. and Tabellini, G. (1994) Is Inequality Harmful for Growth? Theory and Evidence. American Economic Review 84: 600-621

Perugini, C. and Martino, G. (2008) Income Inequality Within European Regions: Determinants and Effects on Growth. Review of Income and Wealth 54: 373-406 
Perugini C., Hölscher J. and Collie, S. (2016) Inequality, Credit and Financial Crises. Cambridge Journal of Economics 40(1): 227-257

Piacentini, M. (2014) Measuring Income Inequality and Poverty at the Regional Level in OECD Countries. OECD Statistics Working Papers, 2014/03, Paris: OECD Publishing

Powell, B., Manish, G.P. and Nair, M. (2010) Corruption, crime and economic growth. in B.L. Benson and P.R. Zimmerman (Eds.) Handbook on the economics of crime, Edward Elgar, London. 328-341

Rajan, R.G. (2010) Fault Lines: How Hidden Fractures Still Threaten the World Economy, Princeton: Princeton University Press

Rice, P., Venables, A.J. (2003) Equilibrium Regional Disparities: Theory and British Evidence. Regional Studies 37(6\&7): 675-686

Rodríguez-Pose, A., Tselios, V. (2010) Inequalities in Income and Education and Regional Economic Growth in Western Europe. Annals of Regional Science 44: 349-375

Roodman, D. (2009) How to do xtabond2: An introduction to difference and system GMM in Stata. The Stata Journal 9 (1): 86-136

Royuela, V. (2015) The Role of Urbanisation on International Migrations. A Case Study of EU and ENP Countries. International Journal of Manpower 36 (4): 469-490

Sanderson, E. and Windmeijer, F. (2016) A Weak Instrument F-Test in Linear IV Models with Multiple Endogenous Variables. Journal of Econometrics 190(2): 212-221

Tselios, V. (2008) Income and educational inequalities in the regions of the European Union. Geographical spillovers under welfare state restrictions. Papers in Regional Science 87(3): 403-431

Voitchovsky, S. (2005) Does the Profile of Income Inequality Matter for Economic Growth? Distinguishing Between the Effects of Inequality in Different Parts of the Income Distribution. Journal of Economic Growth, 10(3): 273-296

World Bank (2006) World Development Report 2006: Equity and Development. Washington, DC: The World Bank 


\section{Figures}

Figure 1. Inequality (Gini Index) and GDP per capita growth: Cross-sectional and time components, OECD regions

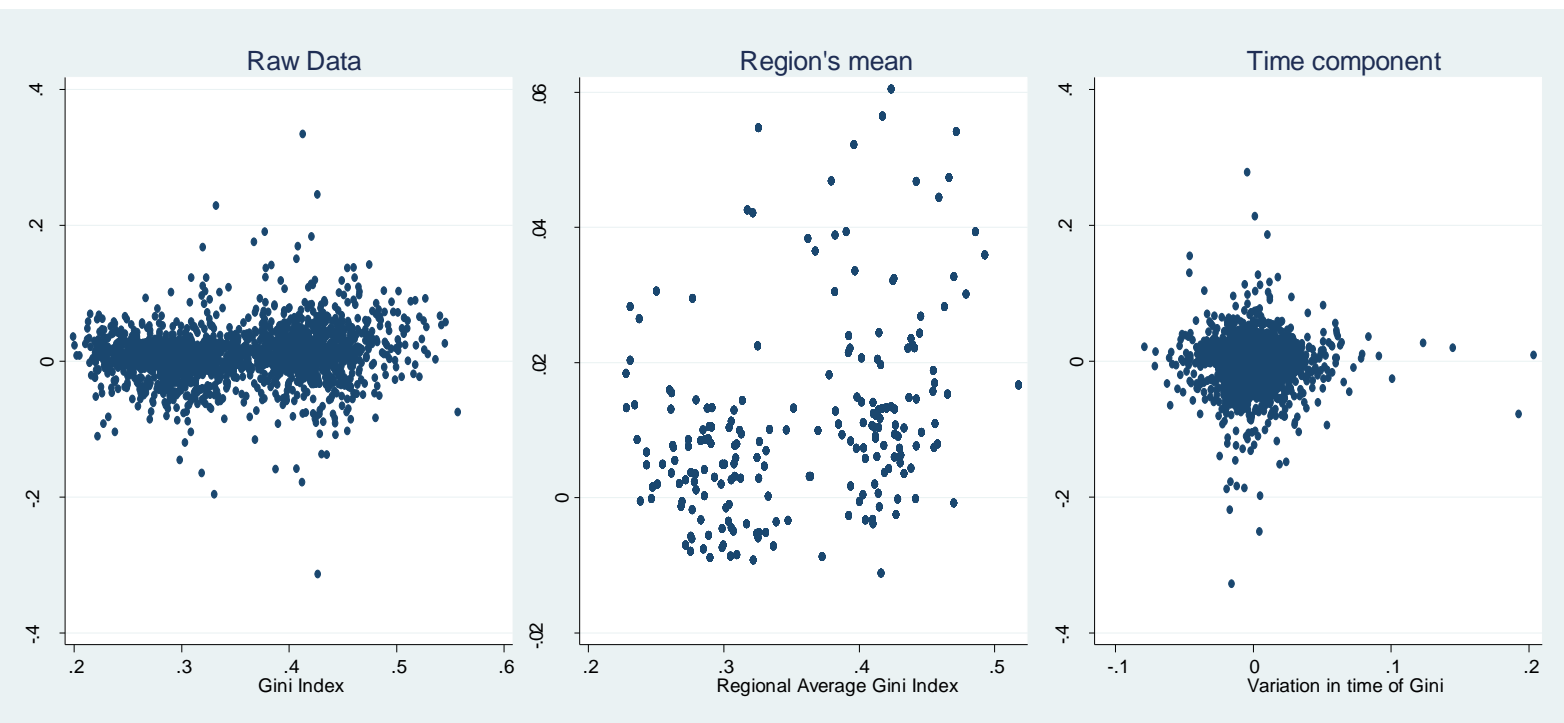

Source: Authors' elaboration based on national household income surveys, various years.

Figure 2. Income inequality by urban size, OECD regions (2003-2013)

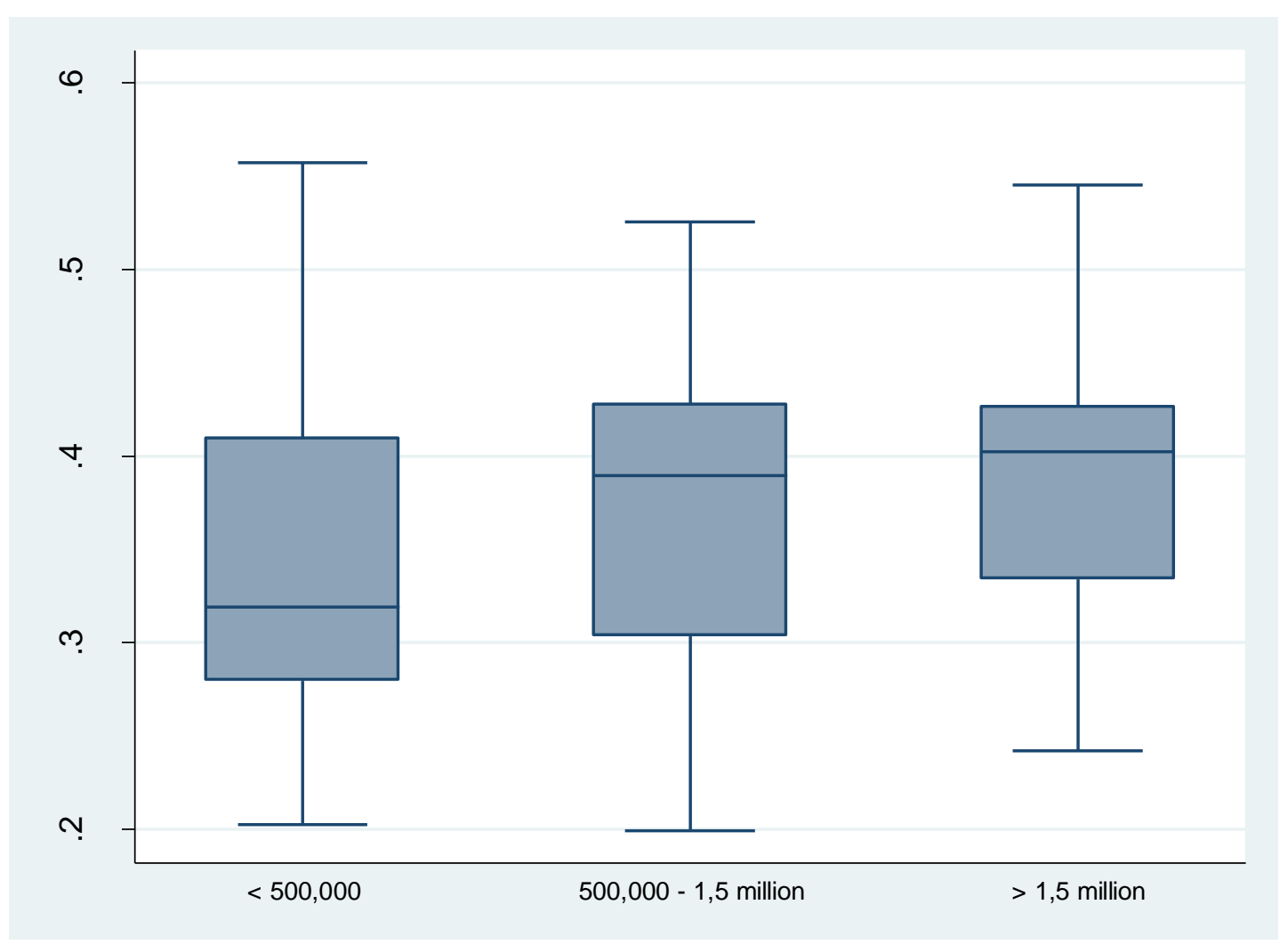




\section{Tables}

Table 1. Correlation coefficients between GDP per capita growth and inequality

\begin{tabular}{lcccccc}
\hline & Gini Index & p80-20 & p90-50 & p50-10 & pov60 & pov40 \\
\hline \multirow{7}{*}{ GDP per capita growth rate } & $\mathbf{0 . 1 4 8}$ & $\mathbf{0 . 0 8 9}$ & $\mathbf{0 . 1 6 3}$ & 0.028 & $\mathbf{0 . 0 4 4}$ & 0.055 \\
& \multicolumn{5}{c}{ Adjusted data } & (region and time dummies) \\
GDP per capita growth rate & -0.015 & -0.019 & 0.033 & $\mathbf{- 0 . 0 4 5}$ & $\mathbf{- 0 . 0 5 3}$ & $\mathbf{- 0 . 0 5 4}$ \\
\hline
\end{tabular}

Note: Bolded correlations are significant at $5 \%$ and italics correlations are significant at $10 \%$. Adjusted data controls for region and time-fixed effects. Computations based on 1,983 observations.

Table 2. Correlation between inequality and urbanisation rates

\begin{tabular}{|c|c|c|c|c|c|c|}
\hline & Gini Index & p80-20 & p90-50 & p50-10 & pov60 & pov40 \\
\hline $\begin{array}{l}\text { Share of people living in FUAs } \\
\text { of small size }(<500,000)\end{array}$ & -0.154 & -0.140 & -0.100 & -0.118 & -0.144 & -0.144 \\
\hline $\begin{array}{l}\text { Share of people living in FUAs } \\
\text { of medium size }(500,000- \\
1.5 \text { million }\end{array}$ & 0.086 & 0.038 & 0.090 & 0.006 & 0.026 & 0.016 \\
\hline $\begin{array}{l}\text { Share of people living in FUAs } \\
\text { of large size }(>1.5 \text { million })\end{array}$ & 0.191 & 0.223 & 0.146 & 0.222 & 0.206 & 0.204 \\
\hline $\begin{array}{l}\text { Share of people living in FUAs } \\
\text { (regardless of size) }\end{array}$ & 0.149 & 0.160 & 0.155 & 0.146 & 0.115 & 0.105 \\
\hline
\end{tabular}

Note: Bold numbers report significant correlations at 5\% and cursive correlations are significant at $10 \%$. 
Table 3. Pooled OLS estimates

\begin{tabular}{|c|c|c|c|c|c|c|c|}
\hline VARIABLES & $\begin{array}{c}(1) \\
\text { Gini }\end{array}$ & $\begin{array}{c}(2) \\
\text { p80-20 }\end{array}$ & $\begin{array}{c}(3) \\
\text { p90-10 }\end{array}$ & $\begin{array}{c}(4) \\
\text { p90-50 }\end{array}$ & $\begin{array}{c}(5) \\
\text { p50-10 }\end{array}$ & $\begin{array}{c}(6) \\
\text { pov40 }\end{array}$ & $\begin{array}{c}(7) \\
\text { pov60 }\end{array}$ \\
\hline ln GDP per capita & $\begin{array}{r}-0.0032 \\
(0.004)\end{array}$ & $\begin{array}{c}-0.0030 \\
(0.003)\end{array}$ & $\begin{array}{r}-0.0027 \\
(0.004)\end{array}$ & $\begin{array}{r}-0.0045 \\
(0.004)\end{array}$ & $\begin{array}{c}-0.0023 \\
(0.003)\end{array}$ & $\begin{array}{c}-0.0026 \\
(0.003)\end{array}$ & $\begin{array}{l}-0.0025 \\
(0.003)\end{array}$ \\
\hline Inequality & $\begin{array}{c}0.0014 \\
(0.024)\end{array}$ & $\begin{array}{c}-0.0004 \\
(0.002)\end{array}$ & $\begin{array}{c}-0.0003 \\
(0.001)\end{array}$ & $\begin{array}{c}0.0070 * \\
(0.004)\end{array}$ & $\begin{array}{c}-0.0035^{* *} * \\
(0.002)\end{array}$ & $\begin{array}{c}-0.0774 * \\
(0.040)\end{array}$ & $\begin{array}{r}-0.0445 \\
(0.031)\end{array}$ \\
\hline Urbanisation $<500,000$ & $\begin{array}{r}-0.0072 \\
(0.008)\end{array}$ & $\begin{array}{r}-0.0069 \\
(0.008)\end{array}$ & $\begin{array}{r}-0.0066 \\
(0.008)\end{array}$ & $\begin{array}{r}-0.0080 \\
(0.008)\end{array}$ & $\begin{array}{r}-0.0053 \\
(0.008)\end{array}$ & $\begin{array}{r}-0.0055 \\
(0.008)\end{array}$ & $\begin{array}{c}-0.0064 \\
(0.008)\end{array}$ \\
\hline Urbanisation $500,000-1.5$ million & $\begin{array}{c}-0.0024 \\
(0.006)\end{array}$ & $\begin{array}{c}-0.0022 \\
(0.006)\end{array}$ & $\begin{array}{c}-0.0020 \\
(0.006)\end{array}$ & $\begin{array}{c}-0.0035 \\
(0.006)\end{array}$ & $\begin{array}{c}-0.0013 \\
(0.006)\end{array}$ & $\begin{array}{c}-0.0013 \\
(0.006)\end{array}$ & $\begin{array}{c}-0.0018 \\
(0.006)\end{array}$ \\
\hline Urbanisation $>1.5$ million & $\begin{array}{r}-0.0009 \\
(0.005)\end{array}$ & $\begin{array}{r}-0.0007 \\
(0.005)\end{array}$ & $\begin{array}{c}-0.0005 \\
(0.005)\end{array}$ & $\begin{array}{r}-0.0023 \\
(0.005)\end{array}$ & $\begin{array}{c}0.0000 \\
(0.005)\end{array}$ & $\begin{array}{l}0.0001 \\
(0.005)\end{array}$ & $\begin{array}{l}-0.0001 \\
(0.005)\end{array}$ \\
\hline Controls & Yes & Yes & Yes & Yes & Yes & Yes & Yes \\
\hline Country fixed effects & Yes & Yes & Yes & Yes & Yes & Yes & Yes \\
\hline Time fixed effects & Yes & Yes & Yes & Yes & Yes & Yes & Yes \\
\hline Observations & 1,793 & 1,793 & 1,793 & 1,793 & 1,793 & 1,793 & 1,793 \\
\hline $\mathrm{R}^{2}$ & 0.401 & 0.401 & 0.401 & 0.402 & 0.402 & 0.403 & 0.402 \\
\hline
\end{tabular}

Note: Robust standard errors in parentheses. ${ }^{*} \mathrm{p}<0.1,{ }^{*} * \mathrm{p}<0.05, * * * \mathrm{p}<0.01$. 
Table 4. RE and IV estimations of models for the Gini Index and the 9050 and 5010 ratios.

\begin{tabular}{|c|c|c|c|c|c|c|}
\hline \multirow{3}{*}{ Inequality } & \multicolumn{2}{|c|}{ RE } & \multicolumn{2}{|c|}{ Pool-IV1 } & \multicolumn{2}{|c|}{ Pool-IV2 } \\
\hline & \multicolumn{6}{|c|}{ Gini Index } \\
\hline & $\begin{array}{l}-0.0011 \\
(0.025)\end{array}$ & $\begin{array}{l}0.0020 \\
(0.026)\end{array}$ & $\begin{array}{c}-1.0612 * * \\
(0.453)\end{array}$ & $\begin{array}{l}-0.2617 \\
(0.176)\end{array}$ & $\begin{array}{l}0.0083 \\
(0.036)\end{array}$ & $\begin{array}{l}0.0615 \\
(0.052)\end{array}$ \\
\hline Inequality * Urb $0.5-1.5$ million & & $\begin{array}{l}-0.0107 \\
(0.009)\end{array}$ & & $\begin{array}{c}-0.2067 * * \\
(0.088)\end{array}$ & & $\begin{array}{l}-0.0800 \\
(0.069)\end{array}$ \\
\hline Inequality $*$ Urb $>1.5$ million & & $\begin{array}{c}-0.0339 * * * \\
(0.011)\end{array}$ & & $\begin{array}{c}-0.2398 * * * \\
(0.080)\end{array}$ & & $\begin{array}{c}-0.1760 * * \\
(0.087)\end{array}$ \\
\hline $\begin{array}{l}\text { Observations } \\
\text { R2 }\end{array}$ & $\begin{array}{l}1,793 \\
0.401\end{array}$ & $\begin{array}{l}1,793 \\
0.403\end{array}$ & 1,688 & 1,688 & 1,58 & 1,58 \\
\hline SW test -Ineqt-1 pval & & & 0.074 & 0.000 & 0.000 & 0.000 \\
\hline $\begin{array}{l}\text { SW test -Ineqt- } 1 * \text { Urb } 0,5-1,5 \mathrm{M} \\
\text { pval }\end{array}$ & & & & 0.000 & & 0.000 \\
\hline $\mathrm{SW}$ test -Ineqt- $1 * \mathrm{Urb}>1,5 \mathrm{M}$ pval & & & & 0.000 & & 0.000 \\
\hline \multirow[t]{2}{*}{ Hansen p-value } & & & 0.752 & 0.230 & 0.139 & 0.566 \\
\hline & \multicolumn{6}{|c|}{ p90-50 ratio } \\
\hline Inequality & $\begin{array}{l}0.0070^{*} \\
(0.004)\end{array}$ & $\begin{array}{l}0.0080 * * \\
(0.004)\end{array}$ & $\begin{array}{c}-0.0762 * * \\
(0.030)\end{array}$ & $\begin{array}{l}0.0160 \\
(0.055)\end{array}$ & $\begin{array}{l}0.0078 \\
(0.006)\end{array}$ & $\begin{array}{l}0.0052 \\
(0.008)\end{array}$ \\
\hline Inequality * Urb $0.5-1.5$ million & & $\begin{array}{l}-0.0013 \\
(0.001)\end{array}$ & & $\begin{array}{c}-0.0409 * \\
(0.024)\end{array}$ & & $\begin{array}{l}0.0104 \\
(0.009)\end{array}$ \\
\hline Inequality $*$ Urb $>1.5$ million & & $\begin{array}{c}-0.0045^{* * *} \\
(0.002)\end{array}$ & & $\begin{array}{c}-0.0517 * \\
(0.028)\end{array}$ & & $\begin{array}{l}-0.0040 \\
(0.011)\end{array}$ \\
\hline $\begin{array}{l}\text { Observations } \\
\text { R2 }\end{array}$ & $\begin{array}{l}1,793 \\
0.402\end{array}$ & $\begin{array}{l}1,793 \\
0.404\end{array}$ & 1,688 & 1,725 & 1,58 & 1,58 \\
\hline SW test -Ineqt-1 pval & & & 0.001 & 0.053 & 0.000 & 0.000 \\
\hline $\begin{array}{l}\text { SW test -Ineqt- } 1 * \text { Urb } 0,5-1,5 \mathrm{M} \\
\text { pval }\end{array}$ & & & & 0.057 & & 0.000 \\
\hline SW test -Ineqt- $1 *$ Urb $>1,5 \mathrm{M}$ pval & & & & 0.059 & & 0.000 \\
\hline \multirow[t]{2}{*}{ Hansen p-value } & & & 0.342 & 0.141 & 0.398 & 0.546 \\
\hline & \multicolumn{6}{|c|}{ p50-10 ratio } \\
\hline Inequality & $\begin{array}{c}-0.0037 * * \\
(0.002)\end{array}$ & $\begin{array}{l}-0.0023 \\
(0.002)\end{array}$ & $\begin{array}{c}-0.0308 * * \\
(0.014)\end{array}$ & $\begin{array}{l}-0.0066 \\
(0.011)\end{array}$ & $\begin{array}{c}-0.0051 * * \\
(0.003)\end{array}$ & $\begin{array}{l}-0.0037 \\
(0.003)\end{array}$ \\
\hline Inequality * Urb $0.5-1.5$ million & & $\begin{array}{r}-0.0013 \\
(0.001)\end{array}$ & & $\begin{array}{r}-0.0162 \\
(0.011)\end{array}$ & & $\begin{array}{l}-0.0030 \\
(0.007)\end{array}$ \\
\hline Inequality $*$ Urb $>1.5$ million & & $\begin{array}{c}-0.0039 * * * \\
(0.001)\end{array}$ & & $\begin{array}{l}-0.0235 * * * \\
(0.008)\end{array}$ & & $\begin{array}{l}-0.0097 \\
(0.007)\end{array}$ \\
\hline Observations & 1,793 & 1,793 & 1,688 & 1,688 & 1,58 & 1,58 \\
\hline $\mathrm{R} 2$ & 0.402 & 0.405 & & & & \\
\hline SW test -Ineqt-1 pval & & & & 0.002 & 0.000 & 0.000 \\
\hline $\begin{array}{l}\text { SW test -Ineqt- } 1 * \text { Urb } 0,5-1,5 \mathrm{M} \\
\text { pval }\end{array}$ & & & & 0.000 & & 0.000 \\
\hline $\mathrm{SW}$ test - Ineqt- $1 * \mathrm{Urb}>1,5 \mathrm{M}$ pval & & & & 0.000 & & 0.000 \\
\hline Hansen p-value & & & 0.153 & 0.121 & 0.409 & 0.290 \\
\hline
\end{tabular}

Notes: Estimations using robust standard errors. ${ }^{*} \mathrm{p}<0.10$, $* * \mathrm{p}<0.05$, $* * * \mathrm{p}<0.01$. SW reports the SandersonWindmeijer (2016) underidentifaction test (SW) of individual endogenous regressors. Hansen J statistic tests the null hypothesis of instrument validity under the assumption of heteroskedasticity. All estimates include country and time fixed effects. All pool IV regressions include time and country fixed effects and all controls listed in table A5 in the Appendix. 
Table 5. Estimation of models by sub-periods

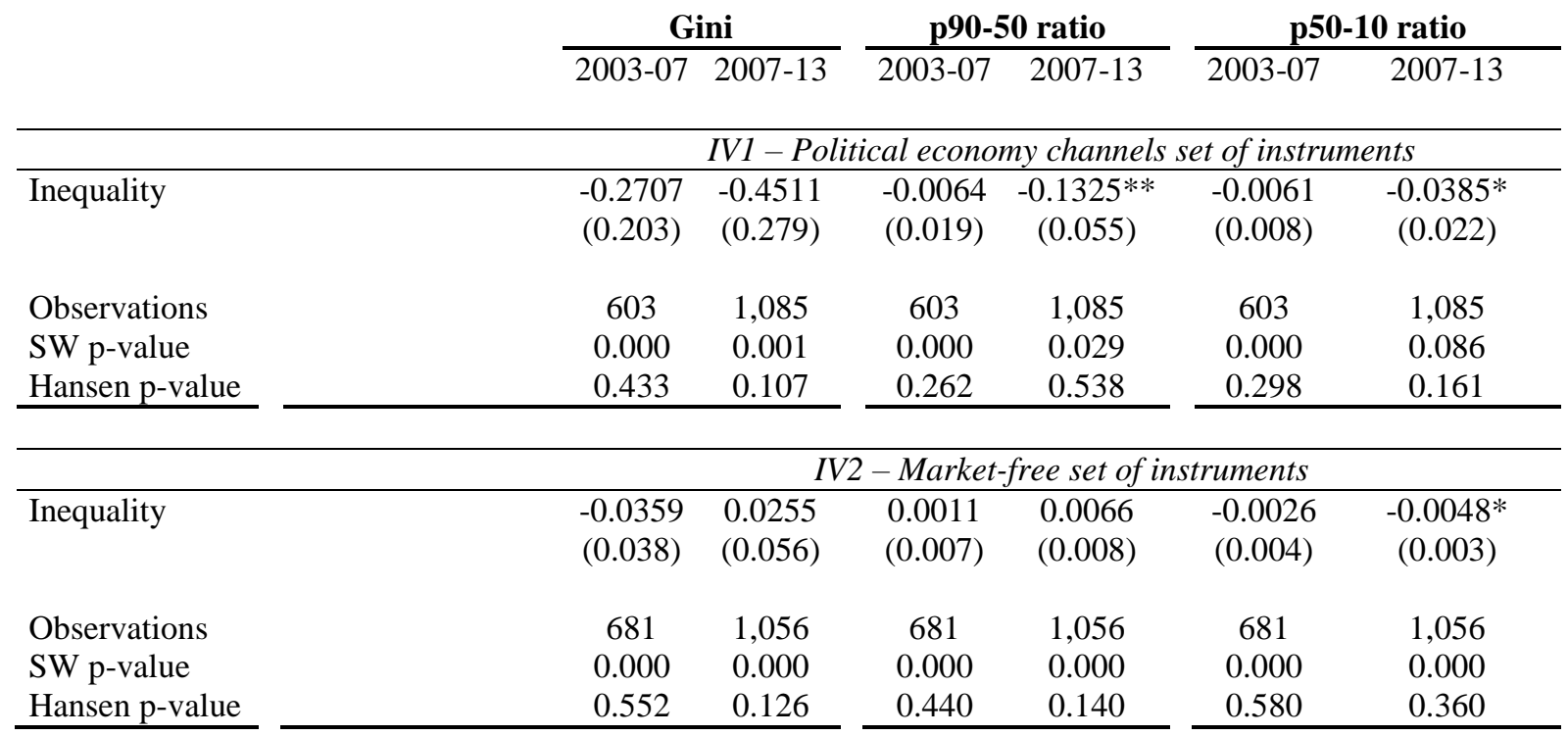

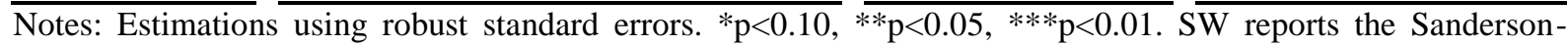
Windmeijer (2016) underidentifaction test (SW) of individual endogenous regressors. Hansen J statistic tests the null hypothesis of instrument validity under the assumption of heteroskedasticity. All estimates include country and time fixed effects. All regressions are pool IV and include time and country fixed effects and all controls listed in table A5 in the Appendix. 


\section{Appendix 1.}

Table A1.1. Mechanisms underlying the relationship between income inequality and economic growth

LONG-TERM

Accumulation of physical and human capital

Higher levels of physical capital investment (rich people have higher savings rates) (Barro, 2000;

Dynan et al., 2004; Kaldor, 1957)
Lower levels of human capital accumulation under credit market imperfections (Bénabou, 2002; Galor and Zeira, 1993; Easterly, 2001)

\section{Economic incentives}

More incentives for competition and risk taking (Rebelo, 1991; Voitchovsky, 2005)
Fewer incentives to borrow (Aghion et al., 1999a)

\section{Political economy arguments}

Higher levels of wealth can induce less effort in the presence of market imperfections due to moral hazard (Aghion et al., 1999a)

Higher taxes allow investment in public education and health (Saint-Paul and Verdier, 1993)
Voters opt for higher taxation and redistribution, decreasing incentives to invest and reducing growth (Alesina and Rodrik, 1994; Persson and Tabellini, 1994)

\section{SHORT-TERM}

\section{Credit market}

Rising inequality can increase credit demand to maintain constant consumption levels (Rajan, 2010).
On the supply side, more loans to more risky individuals can generate financial instability (Perugini et al., 2016)

Demand-side dynamics

Dynamic price effect (those with higher incomes Market size effect (fewer consumers can afford to buy may be more willing to pay for new goods, new goods) (Bertola et al., 2006; Foellmi and stimulating investment and innovation) (Bertola et Zwerimuller, 2006) al., 2006; Foellmi and Zwerimuller, 2006)

\section{Political and macroeconomic instability}

Greater political instability - exacerbated at local level by residential segregation - creates uncertainty and reduces investment, hindering economic growth (Alesina and Perotti, 1996) 


\section{References in table A1.1:}

Aghion, P., Caroli, E., and García-Peñalosa, C. (1999a) Inequality and Economic Growth: The Perspective of the New Growth Theories. Journal of Economic Literature 37: 1615-1660 Alesina, A. and Perotti, R. (1996) Income Distribution, Political Instability, and Investment. European Economic Review 40: 1203-1228

Alesina, A. and Rodrik, D. (1994) Distributive Politics and Economic Growth. The Quarterly Journal of Economics 109: 465-490

Barro, R.J. (2000) Inequality and Growth in a Panel of Countries. Journal of Economic Growth 5: $5-32$

Bénabou, R. (2002) Tax and Education Policy in a Heterogeneous-Agent Economy: What Levels of Redistribution Maximize Growth and Efficiency?. Econometrica 70(2): 471-517

Bertola, G., Foellmi, R., and Zweimüller, J. (2006) Income Distribution in Macroeconomic Models. Princeton: Princeton University Press

Dynan, K.E., Skinner, J., and Zeldes, S.P. (2004) Do the Rich Save More?. Journal of Political Economy 112(2): 397-444

Easterly, W. (2001) The Middle Class Consensus and Economic Development. Journal of Economic Growth 6: 317-335

Foellmi, R. and Zweimuller, J. (2006) Income Distribution and Demand-Induced Innovations. Review of Economic Studies 73(4): 941-960

Galor, O., Zeira, J. (1993) Income Distribution and Macroeconomics. The Review of Economic Studies 60(1): 35-52

Kaldor, N. (1957) A Model of Economic Growth. Economic Journal 67: 591-624

Persson, T. and Tabellini, G. (1994) Is Inequality Harmful for Growth? Theory and Evidence. American Economic Review 84: 600-621

Perugini C., Hölscher J. and Collie, S. (2016) Inequality, Credit and Financial Crises. Cambridge Journal of Economics 40(1): 227-257

Rajan, R.G. (2010) Fault Lines: How Hidden Fractures Still Threaten the World Economy. Princeton: Princeton University Press

Rebelo, S.T. (1991) Long-run Policy Analysis and Long-run Growth. Journal of Political Economy 99: 500-521

Saint-Paul, G., Verdier, T. (1993) Education, democracy and growth. Journal of Development Economics, 42, 399-407.

Voitchovsky, S. (2005) Does the Profile of Income Inequality Matter for Economic Growth? Distinguishing Between the Effects of Inequality in Different Parts of the Income Distribution. Journal of Economic Growth, 10(3): 273-296 
Table A1.2. Data sources for income inequality measures

\begin{tabular}{|l|l|l|l|}
\hline Country & Data source & Years & $\begin{array}{l}\text { Number of } \\
\text { regional } \\
\text { units (TL2) }\end{array}$ \\
\hline Belgium & $\begin{array}{l}\text { European Union Statistics on Income and Living } \\
\text { Conditions (EU-SILC) }\end{array}$ & $2003-2010$ & 3 regions \\
\hline Canada & Survey of Labour and Income Dynamics (SLID) & $2004-2011$ & 10 regions \\
\hline Chile & $\begin{array}{l}\text { Encuesta de Caracterización Socioeconómica } \\
\text { Nacional (CASEN) }\end{array}$ & $\begin{array}{l}2003,2006,2009, \\
2011,2013\end{array}$ & 15 regions \\
\hline Czech Republic & $\begin{array}{l}\text { European Union Statistics on Income and Living } \\
\text { Conditions (EU-SILC) }\end{array}$ & $2004-2010,2012$ & 8 regions \\
\hline Estonia & $\begin{array}{l}\text { European Union Statistics on Income and Living } \\
\text { Conditions (EU-SILC) }\end{array}$ & $2003-2010,2012$ & 1 region \\
\hline Finland & $\begin{array}{l}\text { European Union Statistics on Income and Living } \\
\text { Conditions (EU-SILC) }\end{array}$ & $2003-2010,2012$ & 4 regions \\
\hline France & $\begin{array}{l}\text { European Union Statistics on Income and Living } \\
\text { Conditions (EU-SILC) }\end{array}$ & $2003-2010,2012$ & 22 regions \\
\hline Greece & $\begin{array}{l}\text { European Union Statistics on Income and Living } \\
\text { Conditions (EU-SILC) }\end{array}$ & $2003-2010,2012$ & 4 regions \\
\hline Italy & Indagine sulle condizioni di vita (UDB IT SILC) & $2003-2012$ & 21 regions \\
\hline Korea & Korean Labour \& Income Panel Study (KLIPS) & $\begin{array}{l}2004,2006,2008, \\
2010-2013\end{array}$ & 6 regions \\
\hline Luxembourg & $\begin{array}{l}\text { European Union Statistics on Income and Living } \\
\text { Conditions (EU-SILC) }\end{array}$ & $2003-2010,2012$ & 1 region \\
\hline Mexico & $\begin{array}{l}\text { Encuesta Nacional de Ingreso y Gastos de los } \\
\text { Hogares (ENIGH) }\end{array}$ & $\begin{array}{l}2004,2006,2008, \\
2010,2012\end{array}$ & 32 regions \\
\hline Spain & $\begin{array}{l}\text { European Union Statistics on Income and Living } \\
\text { Conditions (EU-SILC) }\end{array}$ & $2003-2010,2012$ & 19 regions \\
\hline $\begin{array}{l}\text { United } \\
\text { Kingdom }\end{array}$ & $\begin{array}{l}\text { European Union Statistics on Income and Living } \\
\text { Conditions (EU-SILC) }\end{array}$ & $2010,2011,2013$ & 12 regions \\
\hline United States & \begin{tabular}{l} 
Current Population Survey (CPS) \\
\hline
\end{tabular} & $2003-2013$ & 51 regions \\
\hline
\end{tabular}


Table A1.3. Data description

\begin{tabular}{|c|c|c|}
\hline Variable & Definition & Source \\
\hline In GDP per capita & $\begin{array}{l}\text { Log of per capita GDP in constant millions of USD PPP } \\
\text { (reference year 2005) }\end{array}$ & OECD Regional Statistics \\
\hline Gini & Gini Index of household income & $\begin{array}{l}\text { Authors' calculations based on } \\
\text { national income household } \\
\text { surveys }\end{array}$ \\
\hline p80-20 & Quintile ratio & $\begin{array}{l}\text { Authors' calculations based on } \\
\text { national income household } \\
\text { surveys }\end{array}$ \\
\hline p90-10 & Decile ratio & $\begin{array}{l}\text { Authors' calculations based on } \\
\text { national income household } \\
\text { surveys }\end{array}$ \\
\hline p90-50 & Top decile ratio & $\begin{array}{l}\text { Authors' calculations based on } \\
\text { national income household } \\
\text { surveys }\end{array}$ \\
\hline $\mathrm{p} 50-10$ & Bottom decile ratio & $\begin{array}{l}\text { Authors' calculations based on } \\
\text { national income household } \\
\text { surveys }\end{array}$ \\
\hline pov40 & Poverty: poverty line at $40 \%$ of national median income & $\begin{array}{l}\text { Authors' calculations based on } \\
\text { national income household } \\
\text { surveys }\end{array}$ \\
\hline pov60 & Poverty: poverty line at $60 \%$ of national median income & OECD Regional Statistics \\
\hline Urbanisation & $\begin{array}{l}\text { Share of regional population living in OECD functional } \\
\text { urban areas (FUA) }\end{array}$ & $\begin{array}{l}\text { OECD Regional and } \\
\text { Metropolitan Statistics (OECD, } \\
\text { 2012) }\end{array}$ \\
\hline Total population & Total regional population $(\log )$ & OECD Regional Statistics \\
\hline Religion diversity & $\begin{array}{l}\text { Inverse of Herfindahl Index on the shares of different } \\
\text { religions (no sub-aggregates) }\end{array}$ & World Religion Dataset, ATLA \\
\hline $\begin{array}{l}\text { Share of the most popular } \\
\text { religion }\end{array}$ & $\begin{array}{l}\text { Share of the most popular religion (no sub-aggregates } \\
\text { considered) }\end{array}$ & World Religion Dataset, ATLA \\
\hline Agriculture share & $\begin{array}{l}\text { Share of gross value added (GVA) in agriculture, forestry } \\
\text { and fishing over total GVA }\end{array}$ & OECD Regional Statistics \\
\hline Industry share & $\begin{array}{l}\text { Share of GVA in industry, including energy, over total } \\
\text { GVA }\end{array}$ & OECD Regional Statistics \\
\hline Construction share & Share of GVA in construction over total GVA & OECD Regional Statistics \\
\hline $\begin{array}{l}\text { Education share in low } \\
\text { levels }\end{array}$ & $\begin{array}{l}\text { Share of the labour force in lower education levels (0-2 } \\
\text { ISCED groups) }\end{array}$ & OECD Regional Statistics \\
\hline $\begin{array}{l}\text { Education share in average } \\
\text { levels }\end{array}$ & $\begin{array}{l}\text { Share of the labour force in middle education levels (3-4 } \\
\text { ISCED groups) }\end{array}$ & OECD Regional Statistics \\
\hline $\begin{array}{l}\text { Education share in high } \\
\text { levels }\end{array}$ & $\begin{array}{l}\text { Share of the labour force in higher education levels (5-6 } \\
\text { ISCED groups) }\end{array}$ & OECD Regional Statistics \\
\hline Elderly rate & $\begin{array}{l}\text { Elderly rate (ratio between people aged } 65 \text { years or more } \\
\text { and people aged } 15-64 \text { years), expressed in percentage }\end{array}$ & OECD Regional Statistics \\
\hline Unemployment rate & Proportion of unemployed people over total labour force & OECD Regional Statistics \\
\hline $\begin{array}{l}\text { Labour force participation } \\
\text { rate }\end{array}$ & $\begin{array}{l}\text { Participation rate (labour force divided by the working-age } \\
\text { population } 15-64 \text { years old), expressed in percentage }\end{array}$ & OECD Regional Statistics \\
\hline Voters & $\begin{array}{l}\text { Percentage of registered voters who voted during general } \\
\text { elections }\end{array}$ & OECD Regional Statistics \\
\hline Murder rate & Ratio of total murders over 100,000 people & OECD Regional Statistics \\
\hline
\end{tabular}


Table A1.4. Data descriptive statistics

\begin{tabular}{|c|c|c|c|c|c|c|c|}
\hline & \multirow{2}{*}{ Mean } & \multicolumn{3}{|c|}{ Standard deviation } & \multirow{2}{*}{ Minimum } & \multirow{2}{*}{ Maximum } & \multirow{2}{*}{ Regions } \\
\hline & & Overall & Between & Within & & & \\
\hline Total population & 3622937 & 4295609 & 4295707 & 285634.1 & 63303 & $38,000,000$ & 209 \\
\hline GDP per capita & 33951.6 & 17544.18 & 17577.29 & 2900.251 & 5159 & 173750 & 209 \\
\hline $\begin{array}{l}\text { GDP per capita } \\
\text { growth rate }\end{array}$ & 0.0108 & 0.0361 & 0.0142 & 0.0333 & -0.3138 & 0.3340 & 209 \\
\hline Gini Index & 0.3611 & 0.0749 & 0.0717 & 0.0208 & 0.1993 & 0.5572 & 209 \\
\hline p80-20 & 3.0420 & 0.8195 & 0.7640 & 0.2618 & 1.6685 & 8.0888 & 209 \\
\hline p90-10 & 5.8903 & 2.4429 & 2.2785 & 0.7637 & 2.3295 & 23.6075 & 209 \\
\hline p90-50 & 2.2490 & 0.4499 & 0.4216 & 0.1531 & 1.3043 & 4.1827 & 209 \\
\hline $\mathrm{p} 50-10$ & 2.5527 & 0.7309 & 0.6628 & 0.2816 & 1.5129 & 8.3092 & 209 \\
\hline pov40 & 0.0940 & 0.0516 & 0.0484 & 0.0165 & 0.0000 & 0.2859 & 209 \\
\hline pov60 & 0.2099 & 0.0605 & 0.0563 & 0.0210 & 0.0538 & 0.4672 & 209 \\
\hline Urbanisation & 0.5561 & 0.2360 & 0.2337 & 0.0134 & 0.0000 & 1.1628 & 209 \\
\hline Religion diversity & 1.5267 & 0.3669 & 0.3597 & 0.0762 & 1.0622 & 2.9479 & 209 \\
\hline Agriculture share & 3.4491 & 3.6123 & 3.4206 & 1.1595 & 0.0000 & 31.7369 & 209 \\
\hline Industry share & 21.1816 & 11.2430 & 11.1343 & 2.6013 & 0.8607 & 87.9038 & 209 \\
\hline Construction share & 7.1083 & 2.8786 & 2.3956 & 1.5674 & 0.9815 & 30.3747 & 209 \\
\hline $\begin{array}{l}\text { Education share in } \\
\text { lower levels }\end{array}$ & 30.0951 & 18.6921 & 19.0714 & 3.9750 & 2.5955 & 100.0000 & 209 \\
\hline $\begin{array}{l}\text { Education share in } \\
\text { average levels }\end{array}$ & 43.7125 & 15.8637 & 16.0787 & 2.1304 & 0.0000 & 85.3288 & 209 \\
\hline $\begin{array}{l}\text { Education share in } \\
\text { high levels }\end{array}$ & 26.1924 & 10.1120 & 9.5698 & 3.1349 & 0.0000 & 63.9213 & 209 \\
\hline Elderly rate & 20.6112 & 7.7873 & 7.6684 & 1.4500 & 3.6000 & 45.6500 & 209 \\
\hline Unemployment rate & 7.5502 & 4.8759 & 4.0600 & 2.7150 & 0.2000 & 37.0000 & 209 \\
\hline Voters & 65.2286 & 13.6005 & 13.0847 & 3.7715 & 27.6800 & 93.7000 & 209 \\
\hline $\begin{array}{l}\text { Murder rate } \\
\text { (homicides per } \\
\text { million inhabitants) }\end{array}$ & 4.7239 & 8.5108 & 6.4271 & 5.2590 & 0.0000 & 188.5000 & 209 \\
\hline
\end{tabular}

Source: Authors' elaboration based on national household income surveys, various years. 
Figure A1.1. Distribution of urban population by city size over countries. 2010.

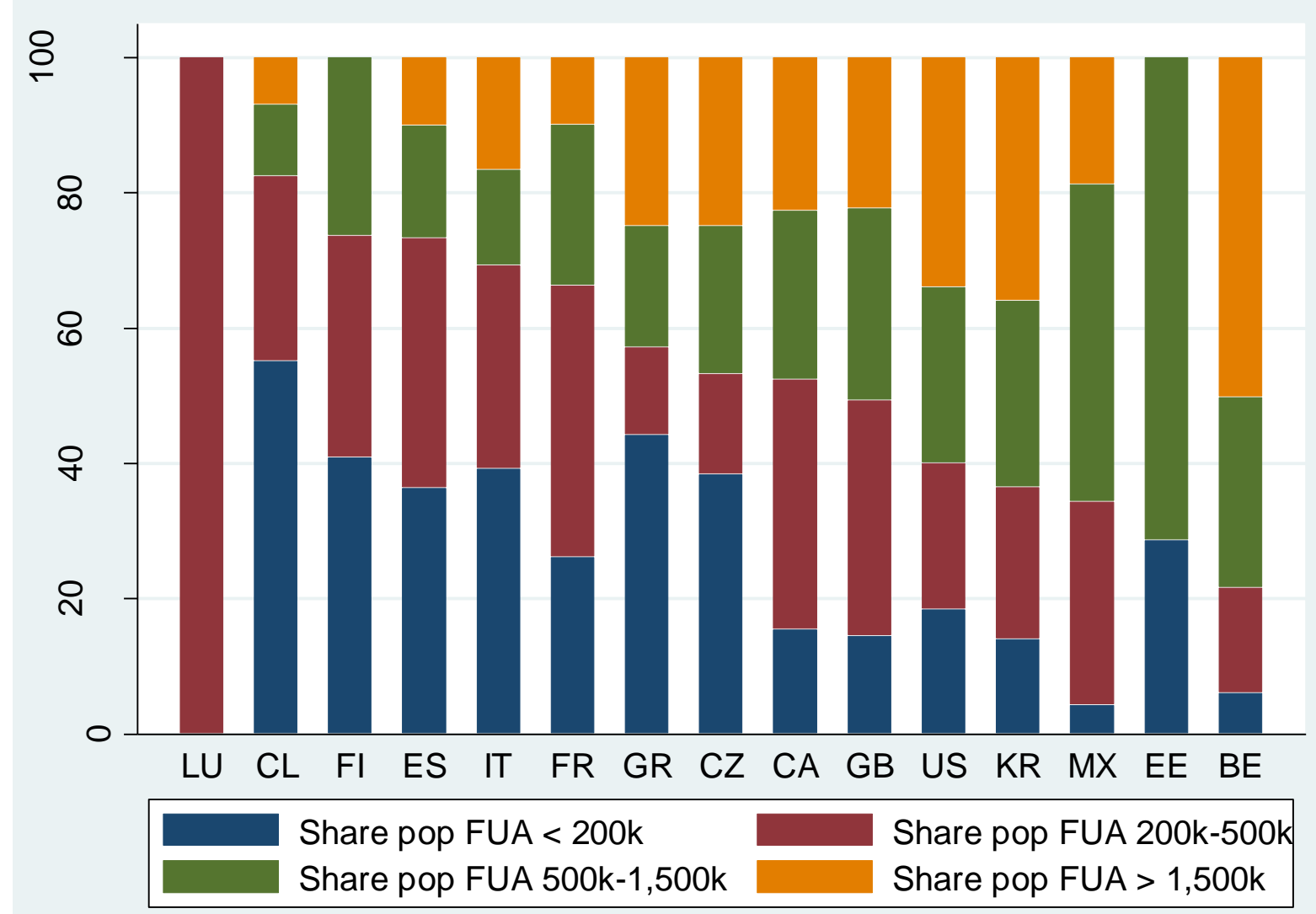


Table A1.5. Pooled OLS estimates

\begin{tabular}{|c|c|c|c|c|c|c|c|}
\hline VARIABLES & $\begin{array}{c}(1) \\
\text { Gini }\end{array}$ & $\begin{array}{c}(2) \\
\text { p80-20 } \\
\end{array}$ & $\begin{array}{c}(3) \\
\text { p90-10 } \\
\end{array}$ & $\begin{array}{c}(4) \\
\text { p90-50 } \\
\end{array}$ & $\begin{array}{c}(5) \\
\text { p50-10 } \\
\end{array}$ & $\begin{array}{c}(6) \\
\text { pov40 }\end{array}$ & $\begin{array}{c}(7) \\
\text { pov60 }\end{array}$ \\
\hline \multirow[t]{2}{*}{ ln GDP per capita } & -0.0032 & -0.0030 & -0.0027 & -0.0045 & -0.0023 & -0.0026 & -0.0025 \\
\hline & $(0.004)$ & $(0.003)$ & $(0.004)$ & $(0.004)$ & $(0.003)$ & $(0.003)$ & $(0.003)$ \\
\hline \multirow[t]{2}{*}{ Inequality } & 0.0014 & -0.0004 & -0.0003 & $0.0070 *$ & $-0.0035 * *$ & $-0.0774 *$ & -0.0445 \\
\hline & $(0.024)$ & $(0.002)$ & $(0.001)$ & $(0.004)$ & $(0.002)$ & $(0.040)$ & $(0.031)$ \\
\hline \multirow[t]{2}{*}{ Urbanisation $<500,000$} & -0.0072 & -0.0069 & -0.0066 & -0.0080 & -0.0053 & -0.0055 & -0.0064 \\
\hline & $(0.008)$ & $(0.008)$ & $(0.008)$ & $(0.008)$ & $(0.008)$ & $(0.008)$ & $(0.008)$ \\
\hline \multirow[t]{2}{*}{ Urbanisation $500,000-1.5$ million } & -0.0024 & -0.0022 & -0.0020 & -0.0035 & -0.0013 & -0.0013 & -0.0018 \\
\hline & $(0.006)$ & $(0.006)$ & $(0.006)$ & $(0.006)$ & $(0.006)$ & $(0.006)$ & $(0.006)$ \\
\hline \multirow[t]{2}{*}{ Urbanisation $>1.5$ million } & -0.0009 & -0.0007 & -0.0005 & -0.0023 & 0.0000 & 0.0001 & -0.0001 \\
\hline & $(0.005)$ & $(0.005)$ & $(0.005)$ & $(0.005)$ & $(0.005)$ & $(0.005)$ & $(0.005)$ \\
\hline \multirow[t]{2}{*}{ Labour force participation rate } & $-0.0004 *$ & $-0.0004 *$ & $-0.0004 *$ & -0.0003 & $-0.0005^{* *}$ & $-0.0005 * *$ & $-0.0005^{*}$ \\
\hline & $(0.000)$ & $(0.000)$ & $(0.000)$ & $(0.000)$ & $(0.000)$ & $(0.000)$ & $(0.000)$ \\
\hline \multirow{2}{*}{$\begin{array}{l}\text { Education share in low levels }(0-2 \\
\text { ISCED) }\end{array}$} & 0.0001 & 0.0001 & 0.0001 & -0.0000 & 0.0001 & 0.0001 & 0.0001 \\
\hline & $(0.000)$ & $(0.000)$ & $(0.000)$ & $(0.000)$ & $(0.000)$ & $(0.000)$ & $(0.000)$ \\
\hline \multirow{2}{*}{$\begin{array}{l}\text { Education share in high levels (5-6 } \\
\text { ISCED) }\end{array}$} & $0.0006 * *$ & $0.0006 * *$ & $0.0006 * *$ & $0.0006^{* *}$ & $0.0006 * *$ & $0.0006^{* *}$ & $0.0006 * *$ \\
\hline & $(0.000)$ & $(0.000)$ & $(0.000)$ & $(0.000)$ & $(0.000)$ & $(0.000)$ & $(0.000)$ \\
\hline \multirow[t]{2}{*}{ Industry share } & $0.0003 *$ & $0.0003^{*}$ & $0.0003 *$ & $0.0003 * *$ & $0.0003 *$ & $0.0003 *$ & $0.0003 *$ \\
\hline & $(0.000)$ & $(0.000)$ & $(0.000)$ & $(0.000)$ & $(0.000)$ & $(0.000)$ & $(0.000)$ \\
\hline \multirow[t]{2}{*}{ Agriculture share } & $0.0010 *$ & $0.0010^{*}$ & $0.0010 *$ & $0.0010 *$ & $0.0009 *$ & $0.0009 *$ & $0.0009 *$ \\
\hline & $(0.001)$ & $(0.001)$ & $(0.001)$ & $(0.001)$ & $(0.001)$ & $(0.001)$ & $(0.001)$ \\
\hline \multirow{2}{*}{ Construction share } & 0.0003 & 0.0003 & 0.0002 & 0.0004 & 0.0002 & 0.0002 & 0.0002 \\
\hline & $(0.000)$ & $(0.000)$ & $(0.001)$ & $(0.000)$ & $(0.001)$ & $(0.001)$ & $(0.000)$ \\
\hline \multirow[t]{2}{*}{ Religion diversity } & $0.0387 * *$ & $0.0390 * *$ & $0.0394 * *$ & $0.0376 * *$ & $0.0412 * *$ & $0.0409 * * *$ & $0.0410 * *$ \\
\hline & $(0.016)$ & $(0.016)$ & $(0.016)$ & $(0.016)$ & $(0.016)$ & $(0.016)$ & $(0.016)$ \\
\hline \multirow[t]{2}{*}{ Constant } & -0.0087 & -0.0092 & -0.0121 & -0.0106 & -0.0131 & -0.0119 & -0.0104 \\
\hline & $(0.045)$ & $(0.045)$ & $(0.045)$ & $(0.046)$ & $(0.044)$ & $(0.043)$ & $(0.044)$ \\
\hline Country fixed effects & Yes & Yes & Yes & Yes & Yes & Yes & Yes \\
\hline Time fixed effects & Yes & Yes & Yes & Yes & Yes & Yes & Yes \\
\hline Observations & 1,793 & 1,793 & 1,793 & 1,793 & 1,793 & 1,793 & 1,793 \\
\hline $\mathrm{R}^{2}$ & 0.401 & 0.401 & 0.401 & 0.402 & 0.402 & 0.403 & 0.402 \\
\hline
\end{tabular}

Note: Robust standard errors in parentheses. $* \mathrm{p}<0.1, * * \mathrm{p}<0.05, * * * \mathrm{p}<0.01$. 
Table A1.6. Estimations of spatial error models for the Gini Index and the 9050 and 5010 ratios (balanced sample $-1,295$ observations $=185$ regions $x 7$ time periods 2004-2010)

\begin{tabular}{|c|c|c|c|c|c|c|}
\hline & RE & Contiguity & Inv. distance & RE & Contiguity & Inv. distance \\
\hline & \multicolumn{6}{|c|}{ Gini Index } \\
\hline Inequality & $\begin{array}{l}0.0078 \\
(0.032)\end{array}$ & $\begin{array}{l}0.0123 \\
(0.031)\end{array}$ & $\begin{array}{l}0.0158 \\
(0.031)\end{array}$ & $\begin{array}{l}0.0108 \\
(0.033)\end{array}$ & $\begin{array}{l}0.0158 \\
(0.032)\end{array}$ & $\begin{array}{l}0.0187 \\
(0.033)\end{array}$ \\
\hline Inequality $*$ Urb $0.5-1.5$ million & & & & $\begin{array}{l}-0.0130 \\
(0.011)\end{array}$ & $\begin{array}{l}-0.0139 \\
(0.011)\end{array}$ & $\begin{array}{l}-0.0127 \\
(0.011)\end{array}$ \\
\hline Inequality $*$ Urb $>1.5$ million & & & & $\begin{array}{c}-0.0462 * * * \\
(0.015)\end{array}$ & $\begin{array}{c}-0.0453 * * * \\
(0.014)\end{array}$ & $\begin{array}{c}-0.0435 * * * \\
(0.014)\end{array}$ \\
\hline Lambda & & $\begin{array}{c}0.1336 * * * \\
(0.047)\end{array}$ & $\begin{array}{c}0.4207 * * * \\
(0.081)\end{array}$ & & $\begin{array}{c}0.1332 * * * \\
(0.047)\end{array}$ & $\begin{array}{c}0.4149 * * * \\
(0.081)\end{array}$ \\
\hline Observations & 1,295 & 1,295 & 1,295 & 1,295 & 1,295 & 1,295 \\
\hline $\mathrm{R} 2$ & 0.409 & 0.409 & 0.409 & 0.413 & 0.413 & 0.412 \\
\hline \multirow[t]{2}{*}{ Pesaran (2004) CD test } & $7.653 * * *$ & & & $7.664 * * *$ & & \\
\hline & \multicolumn{6}{|c|}{ p90-50 ratio } \\
\hline Inequality & $\begin{array}{c}0.0075^{*} \\
(0.004)\end{array}$ & $\begin{array}{c}0.0068 * \\
(0.004)\end{array}$ & $\begin{array}{c}0.0073^{*} \\
(0.004)\end{array}$ & $\begin{array}{c}0.0088 * * \\
(0.004)\end{array}$ & $\begin{array}{c}0.0082 * \\
(0.004)\end{array}$ & $\begin{array}{c}0.0086 * * \\
(0.004)\end{array}$ \\
\hline Inequality $*$ Urb $0.5-1.5$ million & & & & $\begin{array}{l}-0.0017 \\
(0.002)\end{array}$ & $\begin{array}{c}-0.0019 \\
(0.002)\end{array}$ & $\begin{array}{c}-0.0018 \\
(0.002)\end{array}$ \\
\hline Inequality $*$ Urb $>1.5$ million & & & & $\begin{array}{c}-0.0067 * * * \\
(0.002)\end{array}$ & $\begin{array}{c}-0.0067 * * * \\
(0.002)\end{array}$ & $\begin{array}{c}-0.0065 * * * \\
(0.002)\end{array}$ \\
\hline Lambda & & $\begin{array}{c}0.131 * * * \\
(0.048)\end{array}$ & $\begin{array}{c}0.4170 * * * \\
(0.083)\end{array}$ & & $\begin{array}{c}0.130 * * * \\
(0.048)\end{array}$ & $\begin{array}{c}0.4133 * * * \\
(0.083)\end{array}$ \\
\hline Observations & 1,295 & 1,295 & 1,295 & 1,295 & 1,295 & 1,295 \\
\hline $\mathrm{R} 2$ & 0.410 & 0.410 & 0.410 & 0.413 & 0.413 & 0.413 \\
\hline \multirow[t]{2}{*}{ Pesaran (2004) CD test } & $7.527 * * *$ & & & $7.516^{* * * *}$ & & \\
\hline & \multicolumn{6}{|c|}{ p50-10 ratio } \\
\hline Inequality & $\begin{array}{l}-0.0015 \\
(0.003)\end{array}$ & $\begin{array}{l}-0.0009 \\
(0.003)\end{array}$ & $\begin{array}{c}-0.0004 \\
(0.003)\end{array}$ & $\begin{array}{l}0.0009 \\
(0.003)\end{array}$ & $\begin{array}{l}0.0017 \\
(0.003)\end{array}$ & $\begin{array}{l}0.0022 \\
(0.003)\end{array}$ \\
\hline Inequality $*$ Urb $0.5-1.5$ million & & & & $\begin{array}{r}-0.0017 \\
(0.001)\end{array}$ & $\begin{array}{c}-0.0018 \\
(0.001)\end{array}$ & $\begin{array}{c}-0.0018 \\
(0.001)\end{array}$ \\
\hline Inequality $*$ Urb $>1.5$ million & & & & $\begin{array}{c}-0.0054 * * * \\
(0.001)\end{array}$ & $\begin{array}{c}-0.0053 * * * \\
(0.002)\end{array}$ & $\begin{array}{c}-0.0053 * * * \\
(0.002)\end{array}$ \\
\hline Lambda & & $\begin{array}{c}0.133 * * * \\
(0.047)\end{array}$ & $\begin{array}{c}0.4189 * * * \\
(0.082)\end{array}$ & & $\begin{array}{c}0.131 * * * \\
(0.047)\end{array}$ & $\begin{array}{c}0.4144 * * * \\
(0.082)\end{array}$ \\
\hline Observations & 1,295 & 1,295 & 1,295 & 1,295 & 1,295 & 1,295 \\
\hline $\mathrm{R} 2$ & 0.409 & 0.409 & 0.409 & 0.413 & 0.413 & 0.412 \\
\hline Pesaran (2004) CD test & 7.680 *** & & & $7.654 * * *$ & & \\
\hline
\end{tabular}

Notes: Estimations using robust standard errors. ${ }^{*} \mathrm{p}<0.10$, ${ }^{* *} \mathrm{p}<0.05$, $* * * \mathrm{p}<0.01$. All estimates include time and country fixed effects and all controls listed in table A5 in the Appendix. 
Table A1.7. City size differentials in the inequality and growth relationship

\begin{tabular}{|c|c|c|c|c|c|c|c|c|c|}
\hline & \multicolumn{3}{|c|}{ Gini Index } & \multicolumn{3}{|c|}{ p90-50 ratio } & \multicolumn{3}{|c|}{ p50-10 ratio } \\
\hline & $\begin{array}{c}\text { Small } \\
\text { FUAs } \\
(<0,5 \mathrm{M})\end{array}$ & $\begin{array}{c}\text { Median } \\
\text { FUAs } \\
(0,5-1,5 \\
\text { M) }\end{array}$ & $\begin{array}{c}\text { Large FUAs } \\
\quad>1.5 \\
\text { million })\end{array}$ & $\begin{array}{c}\text { Small } \\
\text { FUAs } \\
(<0,5 \\
\text { M })\end{array}$ & $\begin{array}{l}\text { Median } \\
\text { FUAs } \\
(0,5-1,5 \\
\text { M) }\end{array}$ & $\begin{array}{c}\text { Large } \\
\text { FUAs } \\
(>1.5 \\
\text { million })\end{array}$ & $\begin{array}{l}\text { Small } \\
\text { FUAs } \\
(<0,5 \\
\text { M) }\end{array}$ & $\begin{array}{c}\text { Median } \\
\text { FUAs } \\
(0,5-1,5 \\
\text { M) }\end{array}$ & $\begin{array}{c}\text { Large } \\
\text { FUAs } \\
(>1.5 \\
\text { million) }\end{array}$ \\
\hline & \multicolumn{9}{|c|}{ IVI-Political economy channels set of instruments } \\
\hline Inequality & $\begin{array}{c}-0.2994 \\
(0.489)\end{array}$ & $\begin{array}{l}-0.1007 \\
(0.250)\end{array}$ & $\begin{array}{c}-0.5710 * * * \\
(0.215)\end{array}$ & $\begin{array}{l}-0.0490 \\
(0.053)\end{array}$ & $\begin{array}{l}0.0763 \\
(0.057)\end{array}$ & $\begin{array}{l}-0.0225 \\
(0.015)\end{array}$ & $\begin{array}{l}-0.0047 \\
(0.017)\end{array}$ & $\begin{array}{c}-0.0344 * \\
(0.019)\end{array}$ & $\begin{array}{c}-0.0154^{* *} \\
(0.007)\end{array}$ \\
\hline $\begin{array}{l}\text { Observations } \\
\text { SW p-value }\end{array}$ & $\begin{array}{c}757 \\
0.021\end{array}$ & $\begin{array}{c}513 \\
0.031\end{array}$ & $\begin{array}{c}450 \\
0.000\end{array}$ & $\begin{array}{c}757 \\
0.000\end{array}$ & $\begin{array}{c}513 \\
0.025\end{array}$ & $\begin{array}{c}450 \\
0.000\end{array}$ & $\begin{array}{c}757 \\
0.003\end{array}$ & $\begin{array}{c}513 \\
0.011\end{array}$ & $\begin{array}{c}450 \\
0.000\end{array}$ \\
\hline $\begin{array}{l}\text { Hansen p- } \\
\text { value }\end{array}$ & 0.655 & 0.142 & 0.747 & 0.810 & 0.331 & 0.336 & 0.567 & 0.275 & 0.291 \\
\hline & \multicolumn{9}{|c|}{ IV2-Market-free set of instruments } \\
\hline Inequality & $\begin{array}{l}0.0646 \\
(0.049)\end{array}$ & $\begin{array}{l}-0.0690 \\
(0.080)\end{array}$ & $\begin{array}{l}-0.0863 \\
(0.065)\end{array}$ & $\begin{array}{l}0.0020 \\
(0.009)\end{array}$ & $\begin{array}{l}0.0181 \\
(0.011)\end{array}$ & $\begin{array}{l}0.0118 \\
(0.009)\end{array}$ & $\begin{array}{l}-0.0031 \\
(0.003)\end{array}$ & $\begin{array}{c}-0.0113^{*} \\
(0.006)\end{array}$ & $\begin{array}{l}-0.0065 \\
(0.004)\end{array}$ \\
\hline $\begin{array}{l}\text { Observations } \\
\text { SW p-value }\end{array}$ & $\begin{array}{c}730 \\
0.000\end{array}$ & $\begin{array}{c}444 \\
0.000\end{array}$ & $\begin{array}{c}406 \\
0.000\end{array}$ & $\begin{array}{c}730 \\
0.000\end{array}$ & $\begin{array}{c}444 \\
0.000\end{array}$ & $\begin{array}{c}406 \\
0.000\end{array}$ & $\begin{array}{c}730 \\
0.000\end{array}$ & $\begin{array}{c}444 \\
0.000\end{array}$ & $\begin{array}{c}406 \\
0.000\end{array}$ \\
\hline $\begin{array}{l}\text { Hansen p- } \\
\text { value }\end{array}$ & 0.348 & 0.060 & 0.222 & 0.185 & 0.127 & 0.280 & 0.196 & 0.106 & 0.155 \\
\hline
\end{tabular}

Notes: Estimations using robust standard errors. ${ }^{*} \mathrm{p}<0.10, * * \mathrm{p}<0.05, * * * \mathrm{p}<0.01$. SW reports the SandersonWindmeijer (2016) underidentifaction test (SW) of individual endogenous regressors. Hansen J statistic tests the null hypothesis of instrument validity under the assumption of heteroskedasticity. All estimates include country and time fixed effects. All regressions are pool IV and include time and country fixed effects and all controls listed in table 5 . 


\section{Appendix 2.}

\section{Identification strategy for inequality based on industry-mix instruments for economic growth.}

We follow the empirical literature by building valid instruments for inequality by using valid instruments for economic growth. We use a two-step procedure following Brückner $(2012,2013)$ and Castells-Quintana (2016) to adjust simultaneity bias. The starting point is a simultaneous equation model where inequality $\left(\right.$ Ineq $\left._{t}\right)$ and economic growth $\left(\Delta y_{i, t, t+1}\right)$ are mutually related:

$$
\begin{aligned}
& \Delta y_{i, t, t+1}=\alpha\left(\text { Ineq }_{t}\right)+u_{t} \\
& \text { Ineq }_{t}=\theta\left(\Delta y_{i, t-1, t}\right)+e_{t}
\end{aligned}
$$

Our interest is parameter $\alpha$, but if $\theta$ is not zero, OLS estimates in A1 will be biased and inconsistent. In order to overcome this problem we can use instrumental variables for inequality. If we can consistently estimate $\theta$ in A2, we can construct such instruments to be used in A1 by capturing the residual: $\hat{e}_{t}=$ $\operatorname{res}\left(\right.$ Ineq $\left._{t}\right)=\operatorname{Ineq}_{t}-\hat{\theta} \Delta y$. Using this instrument, the IV estimate of A1 will be free of simultaneity bias:

$$
\hat{\alpha}_{I V}=\frac{\operatorname{CoV}\left(\operatorname{res}\left(\operatorname{Ineq}_{t}\right), \Delta y_{i, t, t+1}\right)}{\operatorname{COV}\left(\operatorname{res}\left(\operatorname{Ineq}_{t}\right), \operatorname{Ine} q_{t}\right)}=\alpha+\frac{\operatorname{COV}\left(\operatorname{res}\left(\operatorname{Ine} q_{t}\right), u_{t}\right)}{\operatorname{COV}\left(\operatorname{res}\left(\operatorname{Ine}_{t}\right), \operatorname{Ine} q_{t}\right)}=\alpha+\frac{\operatorname{CoV}\left(e_{t}, u_{t}\right)}{\operatorname{COV}\left(\operatorname{res}\left(\operatorname{Ine} q_{t}\right), \text { Ine }_{t}\right)}
$$

Still, as far as $\operatorname{COV}(e, u) \neq 0$ the omitted variable bias will exist. In order to avoid that bias, we include a large structure of country-period fixed effects in A2 together with additional controls when needed. Castells-Quintana (2016) displays the identification of the adjustment in $\alpha$. In the IV estimation of A1, the first step will be:

$$
\operatorname{Ineq}_{t}=\delta \operatorname{res}\left(\text { Ineq }_{t}\right)+v_{t}=\delta\left(\text { Ineq }_{t}-\hat{\theta} \Delta y_{i, t-1, t}\right)+v_{t}
$$

The residuals of this equation are:

$$
\hat{v}_{t}=\operatorname{Ineq}_{t}-\hat{\delta}\left(\text { Ineq }_{t}-\hat{\theta} \Delta y_{i, t-1, t}\right)
$$


The Control Function Approach (see Woolridge, 2010) allows us to capture the size of the bias by including $\hat{v}_{t}$ in A1:

$$
\Delta y_{i, t, t+1}=\beta_{0} \Delta y_{i, t}+\beta_{1} X_{i, t}+\alpha \operatorname{Ineq}_{i, t}+\varphi \hat{v}+\pi Z_{i, t}+\varepsilon_{i, t}
$$

Which finally turns out to be:

$$
\Delta y_{i, t, t+1}=\beta_{0} \Delta y_{i, t}+\beta_{1} X_{i, t}+(\alpha+\varphi(1-\hat{\delta})) \operatorname{Ineq}_{i, t}+\varphi \hat{\theta} \hat{\delta} \Delta y_{i, t-1, t}+\pi z_{i, t}+\varepsilon_{i, t}
$$

As $\varphi(1-\hat{\delta})$ is the size of the adjustment of the simultaneity bias, which depends on $\varphi$, the role of past growth, $\Delta y_{i, t-1, t}$, in explaining current growth, $\Delta y_{i, t, t+1}$, and $(1-\hat{\delta})$, the share of the variation in Inequality due to economic growth. Given the short-run nature of our data, we expect $\varphi$ to be large, which is an augmenting factor of the bias in non-instrumented estimates.

The instrument proposed for estimating A2 consistently is based on the Industry Mix strategy. The classical industry mix (Bartik, 1991) has been used as an exogenous instrument in local labour market analysis. In our case, we consider the sectoral combination of every region and apply to it the aggregate growth rates for every sector. More recently, Détang-Dessendre et al. (2016) (DDPP onwards) have applied an alternative approach, where the economic growth of every region is regressed against the initial period's sectoral distribution. While the Bartik's industry-mix restricts each sector to the overall growth rate, the authors suggest that this alternative procedure takes into account the sectoral combination impact and allows for differing local multiplier effects when doing separate regressions for subsamples, in our case, different continents. In order to mitigate any endogeneity in industry structure, the sectoral shares are lagged for several years.

We have built several potential instruments. First, we built the Bartik's industry-mix, considering up to four lags of the sectoral structure (labelled as B1 to B4). We have also followed the DDPP regression approach, where regional economic growth is regressed against the sectoral distribution of gross value added, lagged up to four lags. According to these authors, an advantage of the regression approach is that it considers the differing multiplier effects across industries, while Bartik's instrument restricts each sector to the national growth rate, independent of the spillover effects on each sector. We have 
considered two alternatives. The first assumes different parameters in the regression for every country ${ }^{10}$ (labelled as DDPP1 to DDPP4), while the second uses the same set of parameters for all regions in our sample (labelled as DDPP_all_1 to DDPP_all_4). Table A2.1 displays the relationship between economic growth and every alternative instrument, together with the correlation between them. Given the annual nature of our data set, we believe it is normal that these correlations are high compared to those found by DDPP.

Once the instruments for economic growth are defined, we use them to build a valid instrument for inequality in the growth equation. First, we regress inequality on economic growth using an IV approach using the industry mix and the regression-based industry mix as instruments for growth:

$$
\text { Ineq }_{i t}=\rho_{1}\left(\Delta y_{i t-1, t}\right)+a_{i}+b_{t}^{c}+v_{i t}
$$

where $a_{i}$ are region fixed effects, $b_{t}^{c}$ are year fixed effects specific to every continent, which, in turn, allows us to control for a wide range of fixed and time varying omitted variables.

By construction, the residual of such equation captures any variation in the inequality measure that is not due to economic growth. Of course, we have to check for the validity of such variables as instruments for economic growth. Such instruments have to be relevant and exogenous. In order to perform the over identification test, we have also included a second instrument - the vegetation coverage of every region — which can be linked to the weight of agriculture. In such estimations, we have substituted region fixed effects by country specific time dummies in order to avoid perfect identification, so that we are able to compute over identification tests in subsequent steps. Table A2.2 presents first-stage OLS estimations for growth on the sectoral shares instruments.

The second step in building the instrument for inequality in the growth equation consists in regressing inequality on economic growth, which is instrumented by means of the battery of instruments, including Bartik's and DDPP options. For the instruments to be valid, they should not only be relevant (explain economic growth), but should also be exogenous and affect inequality only through economic growth.

\footnotetext{
${ }^{10}$ In order to avoid perfect identification of countries with a single TL2 region, we have merged Luxembourg with Belgium and Estonia with Finland.
} 
In addition to the previous first stage regression, tables A2.3 and A2.4 report the Sanderson-Windmeijer Chi squared test. In most cases the Bartik's based instruments reject at 5\% the null hypothesis of underidentification.

As for exogeneity, we first assume that the sectoral structure of the regional economies and national growth rates are hardly to be affected by local inequality indicators. In order to capture country-specific omitted variables bias, we control for a large set of fixed effects. Table A2.3 reports the estimates of equation A3 for Gini, p9050 and p5010 including regional fixed effects. Table A2.4 shows estimates of equation A3 adding vegetation coverage as a secondary instrument and country specific time dummies. This table displays relevance and exogeneity tests. As can be seen, DDPP4 instruments are robust to the inequality indicator and to the lag structure when building the instrument.

As additional checks, we compute several measures of association between our generated instrument and the dependent variable (and residuals) of our main equation. Thus, as an additional check we have computed the correlation between the residuals of equations A1 and A2 for every indicator of inequality. As reported above, we consider the DDPP4 instrument. Next we display the scatterplots.

Figure A2.1. Gini Index. $\operatorname{corr}(\hat{u}, \hat{e})=0.004$

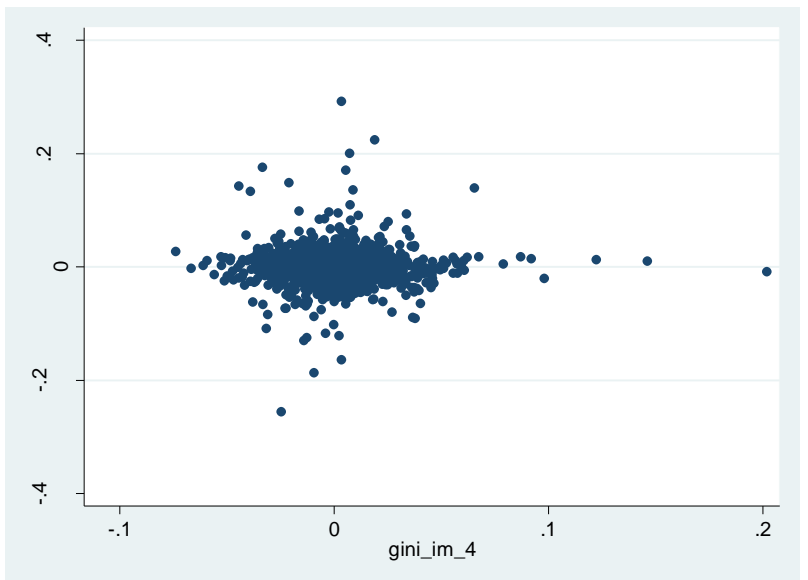

Figure A2.2. P9050. corr ( $(\hat{u}, \hat{e})=-0.0001$ 


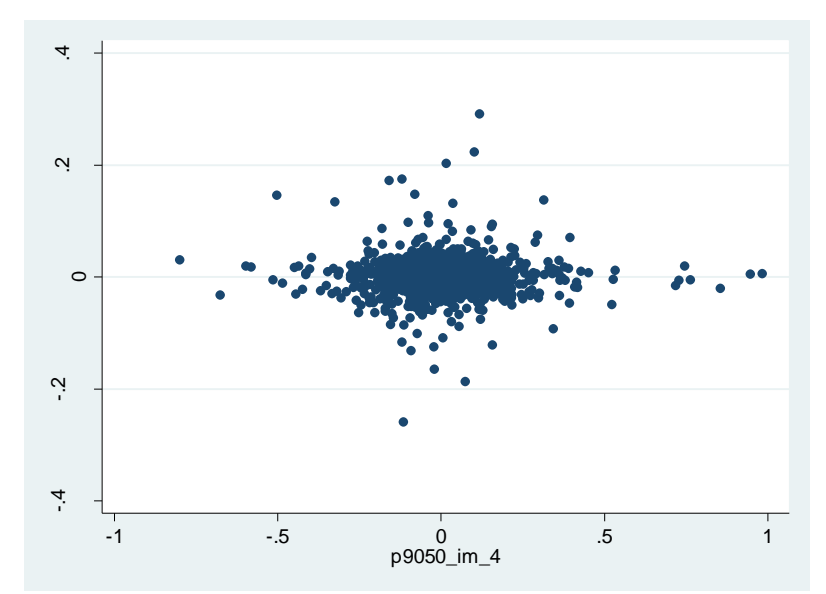

Figure A2.3. P5010. $\operatorname{corr}(\hat{\mathrm{u}}, \hat{\mathrm{e}})=-0.001$

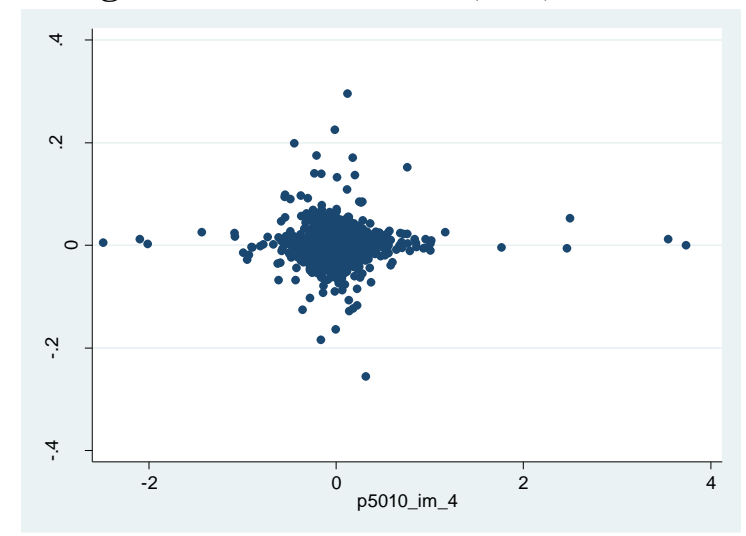

Finally, we have also performed an additional check. We have considered the main regressions substituting the inequality indicator by our generated instrument. In some occasions they arise as significant (p5010). Subsequently we have considered together the inclusion of the inequality indicator and the generated instrument. In these new regressions the generated instrument stops being significant (see Table A2.5). We interpret that as a proof that the instrument is only affecting economic growth through the inequality indicator.

It is important to understand that the sign of the parameters in these regressions is not our main concern. Our aim is to obtain consistent estimates and good instruments for our main regressions. Nevertheless, the analysis of tables A2.3 and A2.4 allows us to see that, economic growth, if any, is associated positively with top income inequality (the most significant parameters in p9050 regressions are positive) and negatively with bottom income inequality (the most significant parameters in p9050 regressions are negative). The observed short run overall effect in income inequality (Gini index) turns out to be mostly 
positive when significant. Consequently, the instruments derived here capture the part of inequality that is not the result of economic growth - what one can interpret as being free of a market channel effect. 
Table A2.1. Pearson correlation coefficient between Economic growth, Bartik and Regression based instruments.

\begin{tabular}{|c|c|c|c|c|c|c|c|c|c|c|c|c|}
\hline & \multicolumn{5}{|c|}{$\begin{array}{l}\text { Bartik's (1991) } \\
\text { instruments }\end{array}$} & \multicolumn{7}{|c|}{ Détang-Dessendre et al. (2016) instruments } \\
\hline & $\begin{array}{c}\text { th } \\
(t+1)\end{array}$ & B1 & B2 & B3 & B4 & $\begin{array}{l}\text { DDP } \\
\text { P1 }\end{array}$ & $\begin{array}{l}\text { DDP } \\
\text { P2 }\end{array}$ & $\begin{array}{l}\text { DDP } \\
\text { P3 }\end{array}$ & $\begin{array}{c}\text { DDP } \\
\text { P4 }\end{array}$ & $\begin{array}{c}\text { DDPP_al } \\
1 \_1\end{array}$ & $\begin{array}{c}\text { DDPP_al } \\
1 \_2\end{array}$ & $\begin{array}{c}\text { DDPP_al } \\
1 \_3\end{array}$ \\
\hline B1 & 0.684 & $\begin{array}{c}1 \\
0.99\end{array}$ & & & & & & & & & & \\
\hline B2 & 0.683 & $\begin{array}{c}9 \\
0.99\end{array}$ & $\begin{array}{c}1 \\
0.99\end{array}$ & & & & & & & & & \\
\hline B3 & 0.682 & $\begin{array}{c}8 \\
0.99\end{array}$ & $\begin{array}{c}9 \\
0.99\end{array}$ & $\begin{array}{c}1 \\
0.99\end{array}$ & & & & & & & & \\
\hline B4 & 0.682 & 7 & 8 & 9 & 1 & & & & & & & \\
\hline DDPP1 & 0.626 & $\begin{array}{c}0.80 \\
0 \\
0.79\end{array}$ & $\begin{array}{c}0.79 \\
6 \\
0.79\end{array}$ & $\begin{array}{c}0.79 \\
4 \\
0.79\end{array}$ & $\begin{array}{c}0.79 \\
9 \\
0.79\end{array}$ & 1 & & & & & & \\
\hline DDPP2 & 0.639 & $\begin{array}{c}6 \\
0.81\end{array}$ & $\begin{array}{c}3 \\
0.81\end{array}$ & $\begin{array}{c}1 \\
0.81\end{array}$ & $\begin{array}{c}5 \\
0.81\end{array}$ & 0.988 & 1 & & & & & \\
\hline DDPP3 & 0.648 & $\begin{array}{c}6 \\
0.81\end{array}$ & $\begin{array}{c}3 \\
0.81\end{array}$ & $\begin{array}{c}2 \\
0.81\end{array}$ & $\begin{array}{c}6 \\
0.81\end{array}$ & 0.969 & 0.981 & 1 & & & & \\
\hline DDPP4 & 0.639 & 7 & 5 & 4 & 8 & 0.971 & 0.975 & 0.980 & 1 & & & \\
\hline $\begin{array}{l}\text { DDPP_al } \\
1 \_1 \\
\text { DDPP al }\end{array}$ & 0.610 & $\begin{array}{c}0.80 \\
6 \\
0.80\end{array}$ & $\begin{array}{c}0.80 \\
2 \\
0.80\end{array}$ & $\begin{array}{c}0.80 \\
1 \\
0.80\end{array}$ & $\begin{array}{c}0.80 \\
4 \\
0.80\end{array}$ & 0.975 & 0.967 & 0.956 & 0.961 & 1 & & \\
\hline DDPP_al & 0.614 & $\begin{array}{c}7 \\
0.81\end{array}$ & $\begin{array}{c}2 \\
0.80\end{array}$ & $\begin{array}{c}1 \\
0.80\end{array}$ & $\begin{array}{c}4 \\
0.81\end{array}$ & 0.972 & 0.971 & 0.961 & 0.963 & 0.997 & 1 & \\
\hline $\begin{array}{l}1 \_3 \\
\text { DDPP_al }\end{array}$ & 0.618 & $\begin{array}{c}2 \\
0.82\end{array}$ & $\begin{array}{c}8 \\
0.81\end{array}$ & $\begin{array}{c}7 \\
0.81\end{array}$ & $\begin{array}{c}0 \\
0.81\end{array}$ & 0.970 & 0.969 & 0.965 & 0.965 & 0.993 & 0.997 & 1 \\
\hline $1 \_4$ & 0.616 & 0 & 5 & 4 & 7 & 0.970 & 0.968 & 0.962 & 0.969 & 0.994 & 0.996 & 0.997 \\
\hline
\end{tabular}


Table A2.2. First-stage OLS estimations for economic growth on the instruments based on sectoral shares

\begin{tabular}{|c|c|c|c|c|c|c|c|c|c|}
\hline & B1 & $\mathrm{B} 2$ & B3 & B4 & DDPP1 & DDPP2 & DDPP3 & DDPP4 & $\overline{D D P P \_a l l}$ \\
\hline Industry Mix & $\begin{array}{c}0.8124 * * * \\
(0.042)\end{array}$ & $\begin{array}{c}0.7941 * * * \\
(0.043)\end{array}$ & $\begin{array}{c}0.8329 * * * \\
(0.047)\end{array}$ & $\begin{array}{c}0.8284 * * * \\
(0.049)\end{array}$ & $\begin{array}{c}1.2360 * * * \\
(0.168)\end{array}$ & $\begin{array}{c}1.4300 * * * \\
(0.150)\end{array}$ & $\begin{array}{c}1.0851 * * * \\
(0.108)\end{array}$ & $\begin{array}{c}0.9753 * * * \\
(0.128)\end{array}$ & $\begin{array}{r}0.9806^{*}= \\
(0.395)\end{array}$ \\
\hline Observations & 2,294 & 2,085 & 1,876 & 1,667 & 2,646 & 2,551 & 2,342 & 2,133 & 2,646 \\
\hline \multirow[t]{2}{*}{ R-squared } & 0.452 & 0.469 & 0.476 & 0.474 & 0.363 & 0.385 & 0.391 & 0.391 & 0.318 \\
\hline & B1 & B2 & B3 & B4 & DDPP1 & DDPP2 & DDPP3 & DDPP4 & DDPP_all \\
\hline$\overline{\text { Industry Mix }}$ & $\begin{array}{c}0.6489 * * * \\
(0.087)\end{array}$ & $\begin{array}{c}0.5892 * * * \\
(0.089)\end{array}$ & $\begin{array}{c}0.5592 * * * \\
(0.106)\end{array}$ & $\begin{array}{c}0.5644 * * * \\
(0.112)\end{array}$ & $\begin{array}{c}0.8087 * * * \\
(0.105)\end{array}$ & $\begin{array}{c}0.8933 * * * \\
(0.088)\end{array}$ & $\begin{array}{c}0.8204 * * * \\
(0.088)\end{array}$ & $\begin{array}{c}0.7982 * * * \\
(0.099)\end{array}$ & $\begin{array}{r}1.0155^{* *} \\
(0.232)\end{array}$ \\
\hline $\begin{array}{l}\text { Vegetation } \\
\text { Coverage }\end{array}$ & $\begin{array}{l}0.0000 \\
(0.000)\end{array}$ & $\begin{array}{l}0.0000 \\
(0.000)\end{array}$ & $\begin{array}{l}0.0000 \\
(0.000)\end{array}$ & $\begin{array}{l}0.0000 \\
(0.000)\end{array}$ & $\begin{array}{l}-0.0000 \\
(0.000)\end{array}$ & $\begin{array}{l}-0.0000 \\
(0.000)\end{array}$ & $\begin{array}{l}-0.0000 \\
(0.000)\end{array}$ & $\begin{array}{l}-0.0000 \\
(0.000)\end{array}$ & $\begin{array}{l}-0.0000 \\
(0.000)\end{array}$ \\
\hline Observations & 2,294 & 2,085 & 1,876 & 1,667 & 2,646 & 2,551 & 2,342 & 2,133 & 2,646 \\
\hline R-squared & 0.492 & 0.504 & 0.500 & 0.497 & 0.494 & 0.515 & 0.520 & 0.522 & 0.485 \\
\hline
\end{tabular}

$\overline{\text { Note: the upper }} \overline{\text { panel includes region fixed effects estimations with continent-specific time dummies. The lower }}$ panel displays estimates including country-specific time dummies. 
Table A2.3. First step estimation for generation Inequality instruments. Instrumental variables estimation.

\begin{tabular}{|c|c|c|c|c|c|c|c|c|c|c|c|}
\hline B1 & B2 & B3 & B4 & DDPP1 & DDPP2 & $\begin{array}{c}\text { DDPP } \\
3\end{array}$ & $\begin{array}{c}\text { DDPP } \\
4\end{array}$ & $\begin{array}{c}\text { DDPP_a } \\
11 \_1\end{array}$ & $\begin{array}{c}\text { DDPP_a } \\
11 \_2\end{array}$ & $\begin{array}{c}\text { DDPP_a } \\
11 \_3\end{array}$ & $\begin{array}{c}\text { DDPP_a } \\
11 \_4\end{array}$ \\
\hline
\end{tabular}

\section{Gini Index}

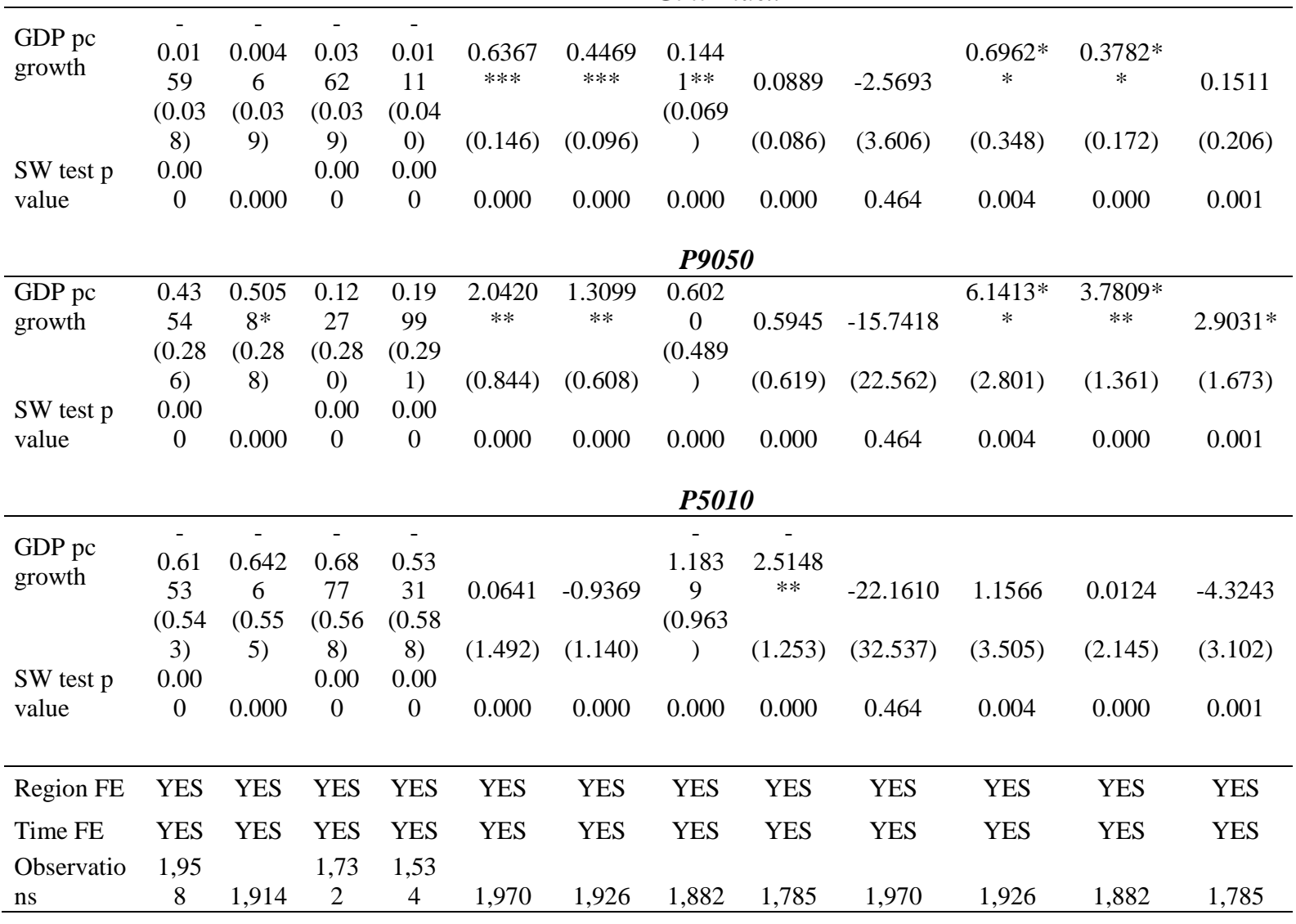


Table A2.4. First step estimation for generation Inequality instruments. TSLS estimates including vegetation coverage as instrument

\begin{tabular}{|c|c|c|c|c|c|c|c|c|c|c|c|c|}
\hline & B1 & B2 & B3 & B4 & $\begin{array}{c}\text { DDPP } \\
1\end{array}$ & $\begin{array}{c}\text { DDPP } \\
2\end{array}$ & $\begin{array}{c}\text { DDPP } \\
3\end{array}$ & $\begin{array}{c}\text { DDP } \\
\text { P4 }\end{array}$ & $\begin{array}{c}\text { DDPP_ } \\
\text { all_1 }\end{array}$ & $\begin{array}{c}\mathrm{DDPP}_{-} \\
\text {all_2 }\end{array}$ & $\begin{array}{c}\mathrm{DDPP}_{-} \\
\text {all_3 }\end{array}$ & $\begin{array}{c}\text { DDPP_ } \\
\text { all_4 }\end{array}$ \\
\hline & \multicolumn{12}{|c|}{ Gini Index } \\
\hline \multirow{4}{*}{$\begin{array}{l}\text { GDP pc } \\
\text { growth }\end{array}$} & 0.05 & 0.04 & 0.04 & 0.21 & - & & & 0.16 & \multirow{2}{*}{-0.3590} & 0.5141 & \multirow{2}{*}{$\begin{array}{c}1.0280 \\
* * *\end{array}$} & \multirow{2}{*}{$\begin{array}{c}1.2394 \\
* * *\end{array}$} \\
\hline & 07 & 82 & 99 & 15 & 0.1655 & 0.0394 & 0.1050 & 40 & & $* *$ & & \\
\hline & $(0.1$ & $(0.1$ & $(0.2$ & $(0.2$ & $(0.130$ & (0.104 & $(0.114$ & $(0.13$ & \multirow{2}{*}{$(0.224)$} & \multirow{2}{*}{$(0.220)$} & \multirow{2}{*}{$(0.291)$} & \multirow{2}{*}{$(0.419)$} \\
\hline & 74) & 77) & 07) & 16) & ) & ) & ) & $0)$ & & & & \\
\hline \multirow{5}{*}{$\begin{array}{l}\text { SW test } p \\
\text { value } \\
\text { Hansen } \mathrm{J} \\
\text { test } \mathrm{p} \text { value }\end{array}$} & 0.02 & 0.01 & 0.01 & 0.01 & 77 & $00^{2}$ & 0 & 0.03 & & & & \\
\hline & 09 & 98 & 53 & 58 & & & & 98 & & & & 6 \\
\hline & 0.08 & 0.13 & 0.22 & 0.39 & 0.140 & 0.1 & 0.245 & 0.51 & 0 & 0.0 & & \\
\hline & 57 & 3 & 6 & 1 & 0.140 & & 0.245 & & & & & \\
\hline & \multicolumn{12}{|c|}{$P 9050$} \\
\hline \multirow{4}{*}{$\begin{array}{l}\text { GDP pc } \\
\text { growth }\end{array}$} & & & & & & & & & \multirow{4}{*}{$\begin{array}{c}4.3938 \\
* *\end{array}$} & & \multirow{4}{*}{$\begin{array}{c}4.7756 \\
* * *\end{array}$} & \multirow{4}{*}{$\begin{array}{c}5.8152 \\
* *\end{array}$} \\
\hline & 1.58 & 1.61 & 0.51 & 1.54 & - & & & 0.93 & & & & \\
\hline & 85 & 27 & 97 & 14 & 1.1273 & 0.2470 & 1.2397 & 95 & & 1.3395 & & \\
\hline & $(1.3$ & $(1.3$ & $(1.5$ & (1.6 & $(0.979$ & $(0.781$ & $(0.856$ & $(0.97$ & & & & \\
\hline \multirow{6}{*}{$\begin{array}{l}\text { SW test } p \\
\text { value } \\
\text { Hansen J } \\
\text { test } p \text { value }\end{array}$} & 80) & 51) & 58) & 35) & ) & ) & ) & 3) & $(1.8$ & $(1.520)$ & $(1.841)$ & $(2.543)$ \\
\hline & 0.02 & 0.01 & 0.01 & 0.01 & & & & 0.03 & & & & \\
\hline & 09 & 98 & 53 & 58 & 0.0357 & 0.0571 & 0.0499 & 98 & 0.0130 & 0.0154 & 0.0141 & 0.0086 \\
\hline & 0.01 & 0.02 & 0.04 & 0.08 & & & & 0.16 & & & & \\
\hline & 87 & 90 & 61 & 27 & 0.0423 & 0.0429 & 0.0633 & 5 & 0.134 & 0.0332 & 0.0627 & 0.174 \\
\hline & \multicolumn{12}{|c|}{$P 5010$} \\
\hline \multirow{4}{*}{$\begin{array}{l}\text { GDP pc } \\
\text { growth }\end{array}$} & & & & & - & - & - & - & - & & \multirow{4}{*}{4.7871} & \multirow{4}{*}{4.8200} \\
\hline & 3.64 & 3.65 & 4.60 & 6.27 & 5.9204 & 4.5551 & 4.3141 & 3.24 & \multirow{3}{*}{$\begin{array}{c}10.890 \\
6 * * *\end{array}$} & & & \\
\hline & 78 & 73 & 49 & $84 *$ & 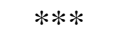 & 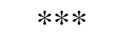 & $* * *$ & $62 *$ & & -1.1510 & & \\
\hline & $(2.3$ & $(2.4$ & $(3.0$ & $(3.2$ & (1.838 & (1.452 & (1.584 & $(1.79$ & & & & \\
\hline \multirow{5}{*}{$\begin{array}{l}\text { SW test } p \\
\text { value } \\
\text { Hansen } J \\
\text { test } p \text { value }\end{array}$} & 56) & 78) & 27) & 64) & ) & ) & ) & 6) & \multirow{4}{*}{$\begin{array}{l}(3.507) \\
0.0130\end{array}$} & (2.699) & \multirow{2}{*}{ (3.072) } & \multirow[t]{2}{*}{ (4.041) } \\
\hline & 0.02 & 0.01 & 0.01 & 0.01 & & & & 0.03 & & & & \\
\hline & 09 & 98 & 53 & 58 & 0.0357 & 0.0571 & 0.0499 & 98 & & 0.0154 & 0.0141 & 0.0086 \\
\hline & 0.68 & 0.54 & 0.47 & 0.18 & & & & 0.11 & & & & \\
\hline & 4 & 3 & 2 & 1 & 0.355 & 0.300 & 0.266 & 7 & 0.290 & 0.373 & 0.464 & 0.201 \\
\hline \multirow{4}{*}{$\begin{array}{l}\text { Country } \\
\otimes \text { Time FE } \\
\text { Observation } \\
\text { s }\end{array}$} & YE & YE & YE & & & & & & & & & \\
\hline & $\mathrm{S}$ & $\mathrm{S}$ & $\mathrm{S}$ & YES & YES & YES & YES & & $\mathbf{Y}$ & & Y & $\mathbf{S}$ \\
\hline & 1,95 & 1,91 & 1,73 & 1,53 & & & & 1,78 & & & & \\
\hline & 8 & 4 & 2 & 6 & 1,970 & 1,926 & 1,882 & 7 & 1,970 & 1,926 & 1,882 & 1,787 \\
\hline
\end{tabular}

Note: Sanderson-Windmiejer (SW) Chi sq tests the significance of excluded instruments, being the null that the endogenous regressor is unidentified. Hansen $\mathrm{J}$ test that the excluded instruments are uncorrelated with the error term. All estimates include the Bartik or the DDPP instruments plus the variable Vegetation Coverage, which allows for computing the Hansen over-identification test. 
Table A2.5. Exogeneity check. Pool OLS estimates

\begin{tabular}{llllll}
\hline$(1)$ & $(2)$ & $(3)$ & $(4)$ & $(5)$ & (6) \\
\hline
\end{tabular}

Dep. Var:

\begin{tabular}{lcccccc} 
Economic growth & \multicolumn{2}{c}{ Gini } & \multicolumn{2}{c}{ P9050 } & \multicolumn{2}{c}{ P5010 } \\
\hline Generated & & & & & \\
Instrument & 0.0142 & 0.0259 & 0.0077 & 0.0062 & $-0.0048^{* *}$ & -0.0041 \\
& $(0.036)$ & $(0.070)$ & $(0.006)$ & $(0.010)$ & $(0.002)$ & $(0.004)$ \\
Inequality & & -0.0119 & & 0.0015 & & -0.0008 \\
& & $(0.053)$ & & $(0.007)$ & & $(0.003)$ \\
Controls & & & & YES & YES & YES \\
Time FE & YES & YES & YES & YES & YES & YES \\
Country FE & YES & YES & YES & YES & YES & YES \\
YES & YES & YES & & & 1,580 \\
Observations & 1,580 & 1,580 & 1,580 & 1,580 & 1,580 & 0.421 \\
R2 & 0.420 & 0.420 & 0.421 & 0.421 & 0.421 & \\
\hline
\end{tabular}

